\title{
An exploratory review of legal texts and literature on living tenure systems in Madagascar
}

Rebecca McLain

Patrick Ranjatson

Tasha Heidenrich

Jean Mananga Rakotonirina

Andrisoa Richard Fabrico Nomenjanahary

Ny Tolotra Ramboatsitoharana Razafimbelo
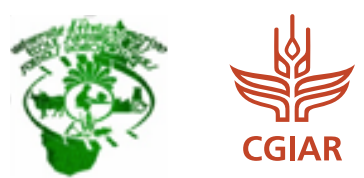

Working Paper 278

\section{An exploratory review of legal texts and literature on living tenure systems in Madagascar}

Rebecca McLain

CIFOR

Patrick Ranjatson

ESSA-Forêts

Tasha Heidenrich

Independent consultant

Jean Mananga Rakotonirina

Independent consultant

Andrisoa Richard Fabrico Nomenjanahary

ESSA-Forêts

Ny Tolotra Ramboatsitoharana Razafimbelo, ESSA-Forêts 
Working Paper 278

(C) 2021 Center for International Forestry Research

(c) (i) Content in this publication is licensed under a Creative Commons Attribution 4.0 International (CC BY 4.0), http://creativecommons.org/licenses/by/4.0/

DOI: $10.17528 /$ cifor/008342

McLain R, Ranjatson P, Heidenrich T, Rakotonirina JM, Nomenjanahary ARF and Razafimbelo NTR. 2021. An exploratory review of legal texts and literature on living tenure systems in Madagascar. Working Paper 278. Bogor, Indonesia: CIFOR.

\section{CIFOR}

Jl. CIFOR, Situ Gede

Bogor Barat 16115

Indonesia

$\mathrm{T}+62(251) 8622-622$

$\mathrm{F}+62(251) 8622-100$

E cifor@cgiar.org

\section{cifor.org}

We would like to thank all funding partners who supported this research through their contributions to the CGIAR Fund. For a full list of the 'CGIAR Fund' funding partners please see: http://www.cgiar.org/our-funders/

Any views expressed in this publication are those of the authors. They do not necessarily represent the views of CIFOR, the editors, the authors' institutions, the financial sponsors or the reviewers. 


\section{Contents}

Abbreviations

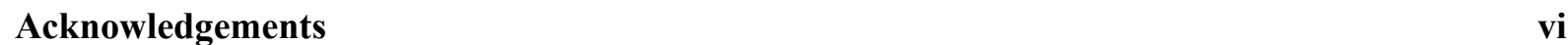

1 Introduction $\quad 1$

2 Legal texts relevant to community-based land tenure $\quad 2$

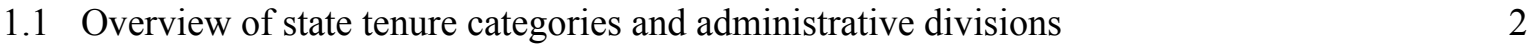

$\begin{array}{llr}1.2 & \text { Local-level collectivities } & 2\end{array}$

1.3 Decentralized territorial collectivities $\quad 3$

$\begin{array}{ll}1.4 \text { Fokontany } & 5\end{array}$

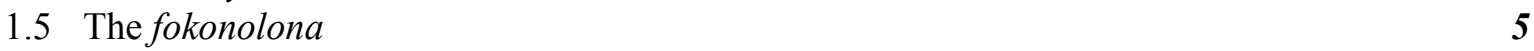

1.6 Legally-established groups: Vondron'olona ifotony (community-based associations) 6

$\begin{array}{lll}1.7 & \text { Community and land tenure } & 7\end{array}$

$\begin{array}{llr}1.8 \text { Legal texts cited } & 8\end{array}$

3 Key themes in local-level land governance in Madagascar $\quad 10$

$\begin{array}{ll}2.1 \text { Introduction } & 10\end{array}$

2.2 Legal pluralism: Intersecting state and customary tenure and governance systems 10

$\begin{array}{lll}2.3 \text { Local customary governance } & 13\end{array}$

$\begin{array}{ll}2.4 \text { Dina: Where customary and state law meet } & 17\end{array}$

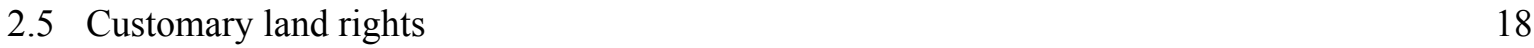

$\begin{array}{ll}2.6 & 19\end{array}$

$\begin{array}{lll}2.7 & \text { Local land-use categories and associated tenure rights } & 21\end{array}$

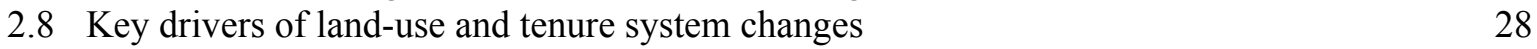

$\begin{array}{lll}2.9 & \text { Key research gaps } & 29\end{array}$

4 Conclusion $\quad 31$

$\begin{array}{ll}\text { References } & 33\end{array}$

\section{List of figures, table and boxes}

\section{Figures}

1 Madagascar's parallel governance structure. 3

2 Regions of Madagascar $\quad 11$

3 Location of selected studies $\quad 12$

\section{Table}

1 Ethnic groups of Madagascar $\quad 14$

\section{Boxes}

1 Examples of land governance structures $\quad 15$

2 Dina in Ambodilaingo (Beforona Commune) 17

3 Privatization of a resource commons 24

4 Examples of sacred forest rules in Madagascar 27 


\section{Abbreviations}

COBA

DTC

CGF

GELOSE

SFR

VOI

PAG

IRD

ORSTOM
Association de communauté de base (community-based association)

Decentralized territorial collectivity

Contrat de gestion forestier

Gestion locale sécurisée (secure local management)

Sécurisation foncière relative (relative tenure security)

Vondron'olona ifotony (community-based association)

Plan d'aménagement et de gestion (development and management plan)

Institut de Recherche pour le Développement

Office de la Recherche Scientifique et Technique Outre-mer

\section{Malagasy glossary}

ala
ala be
alafady
ala fano-hofa
ala kibory
ala mandiniky
ampanjaka
baiboho
dina
fady, faly
famahidana
fanjakana
fatidra
fiarana
fihavanana
filongoa
fokonolona; fokonolo
fokontany
havana
karazaña
kija
kily
kitay telo an-dalana

kizo

lazo

lilin-draza

lonaky

mandaminy forest

large forest

taboo/sacred forest

honey groves (Androy)

forest patches with tombs (Androy)

small degraded forest (Sakalava)

king

seasonally flooded lowlands

local bylaws; social convention

taboo

turning of the bones ritual

state authorities

blood-mixing ritual

Cooperation

solidarity

social cohesion, but generally encompasses primarily patrilineal kin

state-sanctioned but locally legitimate village council

lowest administrative level of the state

family

ethnic group/tribe

area where zebul are gathered (to eat, drink, get washed, rest)

tamarind tree

traditional division of property upon divorce (two-thirds to husband; one-third to wife)

paths for zebu to circulate

cut tree

rules of the ancestors

traditional authorities

setting relationships straight

1 A zebu is a species or subspecies of domestic cattle originating in the Indian sub-continent, characterized by a fatty hump on their shoulders, a large dewlap, and sometimes drooping ears. 


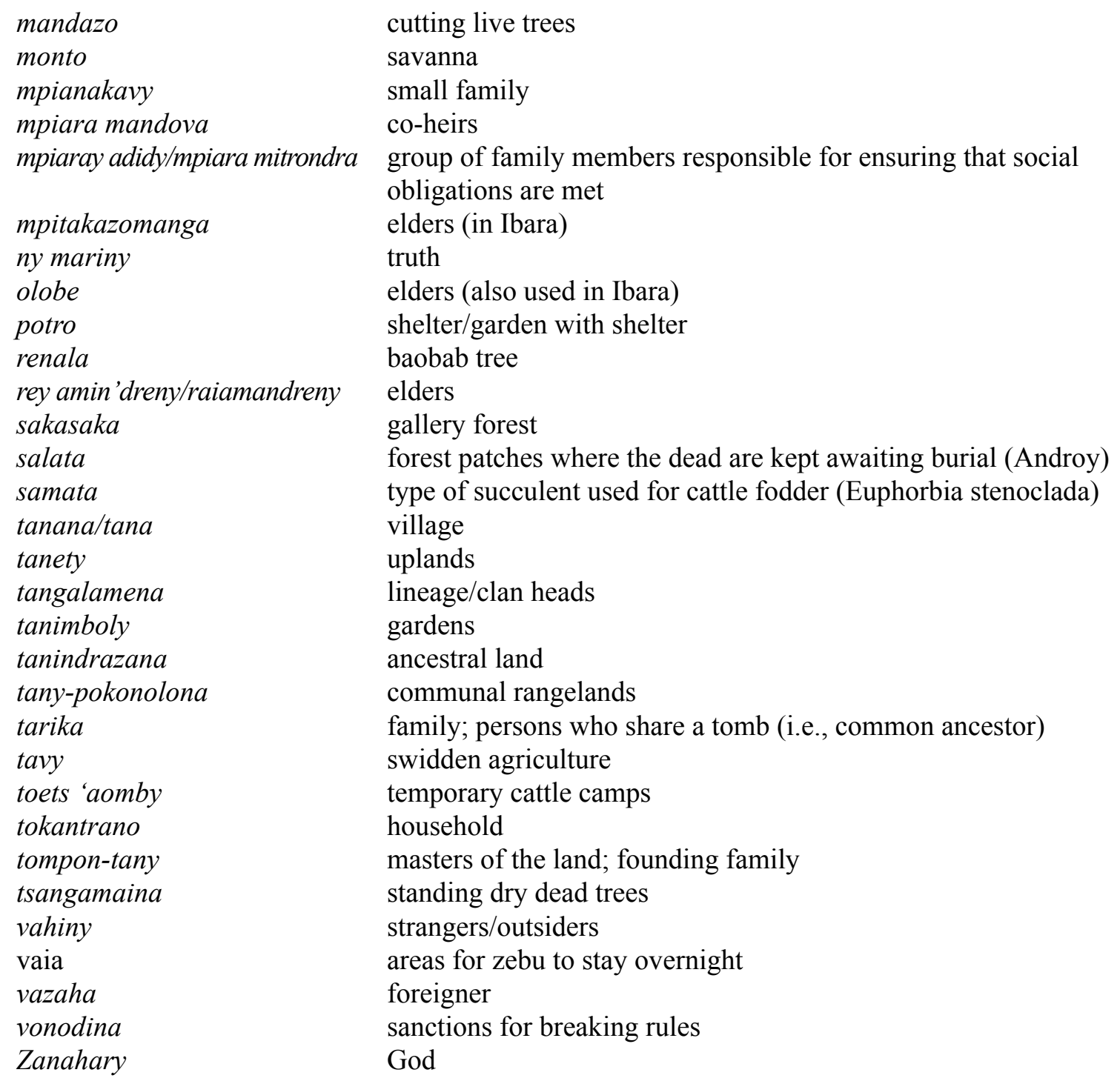




\section{Acknowledgements}

This work was funded through and undertaken as part of the CGIAR Research Programs on Policies, Institutions, and Markets (PIM), led by the International Food Policy Research Institute (IFPRI), and Forest, Trees and Agroforestry (FTA), led by CIFOR. This working paper has not gone through IFPRI's standard peer-review procedure. The opinions expressed here belong to the authors, and do not necessarily reflect the views of CIFOR, PIM, IFPRI, CGIAR or the financial sponsors.

Special thanks to Andrisoa Richard Fabrico Nomenjanahary for producing the maps used in this report. We also express our gratitude to Nantenaina Fitiavana Jean Renaud Randrianasolo for the insights into pastoralist tenure systems, and to Anne Larson for her intellectual support throughout. 


\section{Introduction}

In 2018-2019, the Center for International Forestry Research (CIFOR), working with its Malagasy partner, the University of Antananarivo's École Supérieure des Sciences Agronomiques - Forêts (ESSA-Forêts), conducted a research project in Boeny Region in northwestern Madagascar aimed at understanding how land tenure is likely to affect efforts to support widespread engagement in forest landscape restoration (Ranjatson et al. 2019). This Boeny study suggested that the current land law provides inadequate security for rural lands that are held and managed collectively (McLain et al. 2019). How to determine which entity or entities should have legal recognition as collectivities, and thus the legal personality that would allow them to hold and administer land rights, is currently under debate in Madagascar.

Well-intentioned efforts to provide rural residents with individualized land certificates - under the 2005 Land Law - risk undermining collective rights to forest, grazing and other commons (McLain et al. 2019). Such commons are precisely those areas most likely to be targeted for forest landscape restoration. However, a lack of information about living customary systems - that in practice govern the use of such commons - hampers efforts to identify the level or levels at which collectivities charged with allocating land and enforcing land claims should receive legal recognition. We describe these systems as 'living' customary tenure systems to emphasize that they are customary systems that are dynamic, but that also have been and continue to be heavily influenced by colonial ${ }^{1}$ and postindependence state tenure systems. This working paper seeks to fill some of the knowledge gaps about living customary systems through a review of field studies of tenure systems as they manifest themselves on the ground in Madagascar and an overview of relevant legal texts. The review will inform ongoing efforts to incorporate collectively-held lands into Madagascar's land policy and law.

The paper is divided into two sections. Section 1 provides an overview of legal texts likely to influence opportunities for strengthening community-based tenure systems. The texts examined cover: 1) Decentralized territorial collectivities, with a focus on rural communes, which have responsibility for administering the land certification system established by Madagascar's 2005 Land Law; 2) fokontany, the lowest level of the state apparatus; 3) fokonolona, community assemblies associated with the fokontany; and 4) community-based forest management associations. Section 2 summarizes key patterns and themes related to the 'living' customary tenure systems examined in our review.

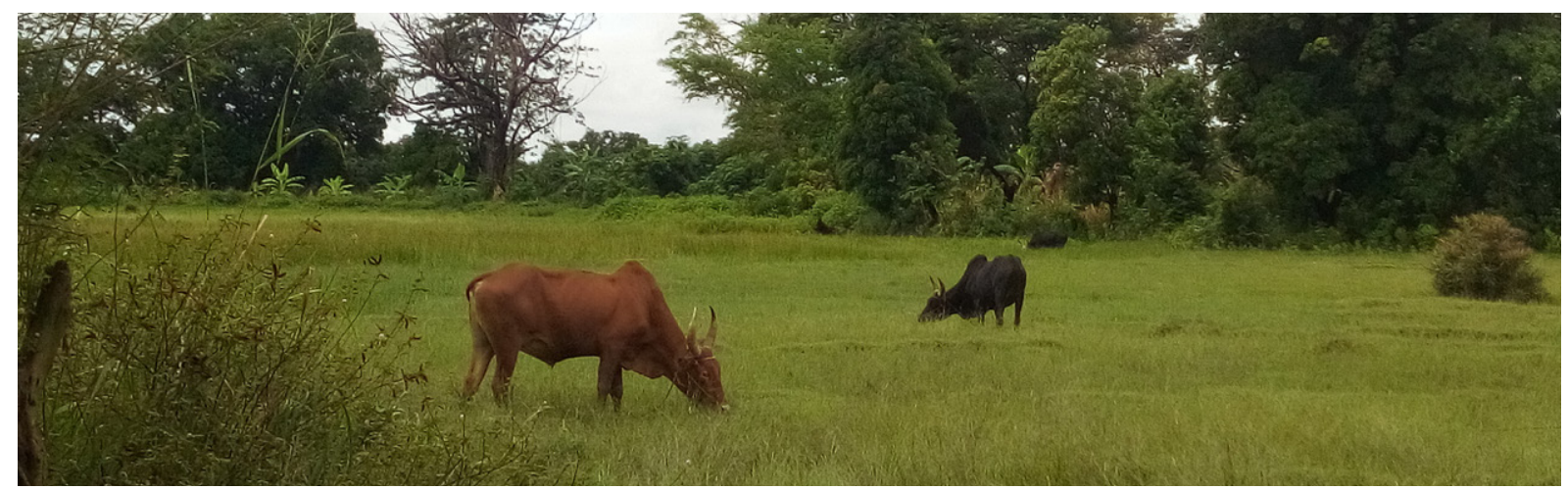

Zebu cattle grazing in northwest Madagascar Photo by Ny Tolotra Razafimbelo/ESSA-Forêts

1 Although emphasis is often placed on the impacts of the French colonial system on Malagasy tenure systems, it should not be forgotten that indigenous colonial systems, notably those of the Merina and Sakalava kingdoms, also influenced customary tenure systems in many parts of the island. 


\section{Legal texts relevant to community-based land tenure}

We begin with a brief description of Madagascar's state-based tenure categories and administrative divisions to help situate readers unfamiliar with the island.

\subsection{Overview of state tenure categories and administrative divisions}

Prior to 2005, Madagascar's land law was based on the presumption of state ownership. In brief, any land that had not undergone titling through the state-administered land titling system was considered to belong to the state. This meant that most land in rural Madagascar, the majority of which had never been titled and continued to be informally governed by customary law, was considered state property. The 2005 Land Law replaced the presumption of state ownership with the presumption of private ownership under customary tenure, for untitled lands that were occupied. Under the 2005 Land Law, land was divided into three major categories: state lands (public and private); private, untitled lands (known as propriété privée, non-titrée, or PPNT); and lands with special status (for example, national parks, forest reserves, and protected areas). In effect, the 2005 Land Law recognizes customary tenure rights for farmland, residential areas and tree plantations, but not for forests or grazing lands (Jones et al. 2018).

Madagascar has a parallel system of governance, consisting of four levels of deconcentrated state administrative units (prefectures, districts, administrative arrondissements, and fokontany) and two types of decentralized territorial collectivities (regions and communes) (Figure 1). Additionally, each fokontany has a fokonolona, or community assembly consisting of all persons 18 and over who live in the fokontany. The deconcentrated units are organized hierarchically, whereas the regions and communes are autonomous of each other and of the deconcentrated administrative units.

The country's 23 regions are geographically partitioned into districts. Districts are subdivided into administrative arrondissements, and each district has multiple autonomous communes within its borders. Administrative arrondissements are subdivided into fokontany; each commune also has multiple fokontany within its borders. The region head and commune mayor, as well as the regional and communal council members are elected by popular vote. Both the regions and the communes exercise financial autonomy.

The fokontany are the deconcentrated state administrative units closest to most of Madagascar's rural population. The fokontany head and deputy are selected by the district head from a list of candidates provided by the fokonolona, the community assembly associated with each fokontany. The fokonolona corresponds very closely to Malagasy institutions that traditionally governed at the village level. However, as will be described in greater detail in this section, it is unclear whether a pathway exists within the state legal system for fokontany or fokonolona to be recognized as landholders.

\subsection{Local-level collectivities}

Four major types of local-level collectivities - communes, fokontany, fokonolona and communitybased associations (COBA) - currently play important roles in land administration within the state's legal framework. This section provides an overview of these collectivities and their land administration roles as defined and described in various state-based laws, orders and decrees. 


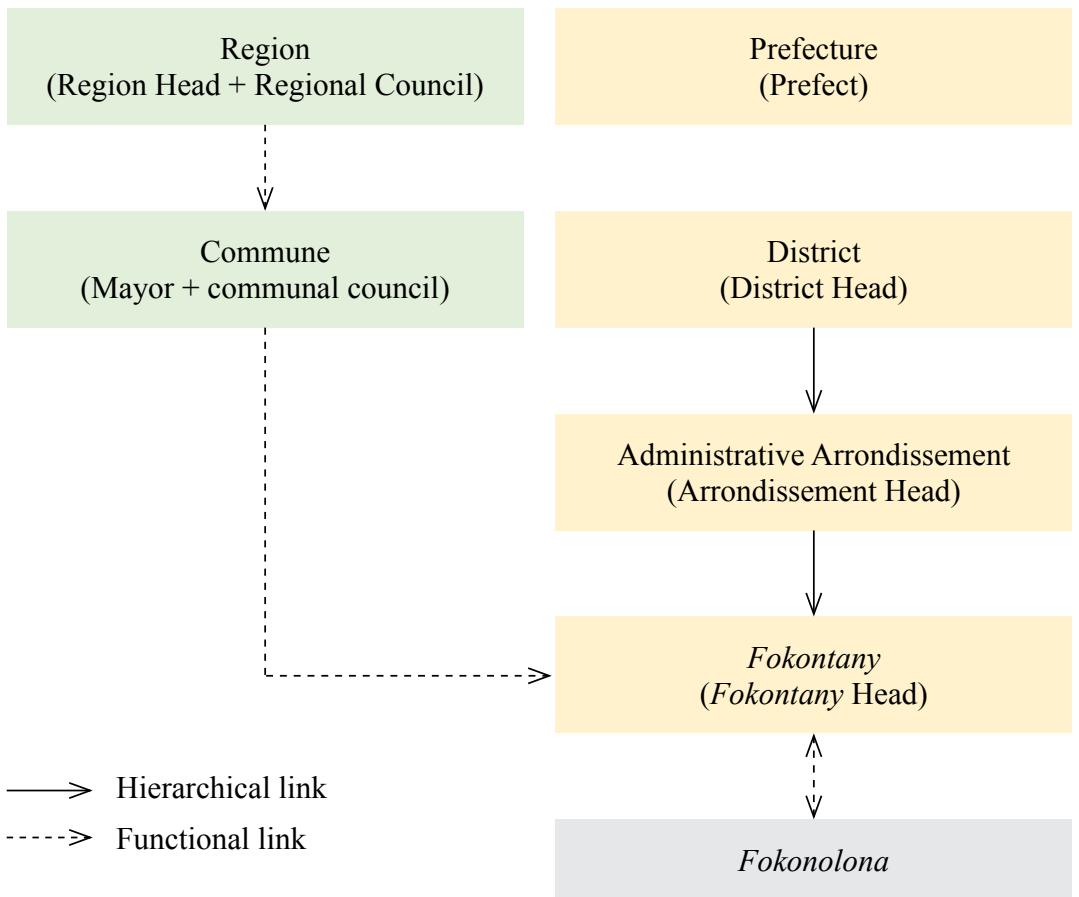

Figure 1. Madagascar's parallel governance structure.

Blue boxes represent decentralized territorial collectivities. Green boxes represent deconcentrated state administrative units. The gray oval represents the fokonolona, or community assembly, a non-state entity.

\subsection{Decentralized territorial collectivities}

The decentralized territorial collectivity (DTC) is "a proportion of the national territory (...) endowed with a legal personality and financial autonomy" (Article 1, Law 94-008). In addition, according to Law 2004-001, Article 6, it is endowed with "social solidarity with a geographical place, taking into account socio-cultural factors". Law 2014-18 of September 12, 2004 regulating the DTCs' competencies and modes of operation provides for three autonomous DTCs (province, region, commune), but currently only regions and communes are functional. Here, we will focus on the commune $^{2}$, since it is the DTC closest to local communities.

\subsubsection{Role of decentralized territorial collectivities in the state land tenure system}

\section{Decentralized territorial collectivities' private holdings}

DTCs can possess and manage lands registered in their name. These lands allow them to accomplish their roles. In the case of communes, such roles include the provision of basic administrative, social and health services and administering the land certification system introduced under the 2005 Land Law (Law 2005-019 of 17 October 2005 regarding the principles related to land tenure categories).

2 Starting in the 1990s, Madagascar shifted administrative and financial authorities to decentralized territorial collectivities (DTCs). The lowest-level DTC, the communes, were established in 1996 (World Bank 2004). Regions, which encompass multiple communes, were established in 2004 (Bidou et al. 2008). The communes have emerged as the key decentralized governance entities at the local level (Bidou et al. 2008). Article 139 of the 2010 Constitution gives the DTCs juridical personalities along with administrative and financial autonomy. Article 140 gives the DTC regulatory powers within its territory and the right of selfgovernance. The mayor, the commune's executive officer and commune council members are elected (Bidou et al. 2008). 


\section{Land registration for territorial collectivities}

Under Ordinance 60-146, Article 153 and Law 60-004, Article 31), a territorial collectivity can apply for collective registration of the lands located within its territory. Collective registration began under the French colonial regime through implementation of an indigenous cadastre, a procedure for recognizing the land rights of Malagasy inhabitants. Despite its name, collective registration does not seek to register collective rights, but rather is a collectively implemented procedure for establishing and recording the rights of individuals to plots belonging to the members of the community concerned. After the abrogation of the native cadastre law following independence, native cadastral titles were transformed into state land titles, and any subsequent cadastral procedures were continued through collectively implemented land registration. Although the law specifies that the territorial collectivity initiates the collective land registration procedure, the final beneficiaries of the title deeds are the individuals who demonstrate proof of occupation or development. In other words, under this procedure, land registration is implemented as a collective process, but the plots of land registered during the procedure are registered in the names of individuals.

\section{State land grants to territorial collectivities}

According to Law 60-004 of 15 February 1960, a territorial collectivity can request a land grant (donation) from the state's private domain. A donation is a conditional provision of land accompanied by development conditions. Such requests are intended to be used for portions of the state's private domain where residents of the territorial collectivity in question exercise collective enjoyment. The procedure is initiated by a commission set up by decree, and the donation is also pronounced by decree.

During the donation process, the collectivity has the responsibility to:

- Resolve internal conflicts over parcels (Article 155).

- Define, through an advisory council, collective use zones and collective development zones (Article 37); collective use zones do not permit registration of the land in the name of the beneficiaries (Article 54), whereas zones for collective development can be registered in the name of the beneficiaries.

- Define the vocation of land, which can be "forestry and protection", "pasture" or "agriculture and intensive livestock" (Article 1 of Ordinance 62-123).

Lands obtained as donation can become individual properties or can be for collective use, subject to compliance with the respective conditions of use. The territorial collectivity is the custodian of the written record (procés-verbal, PV) that confirms occupancy (i.e., collective land tenure security) and of the collective land occupancy plan, and is responsible for future modifications, like the extension of plots, etc.

\section{Land management and conservation}

In 1996, Law 96-025 introduced Gestion Locale Sécurisée (Loi GELOSE), or secure communitybased management, a form of co-management between local communities and the Malagasy state on lands belonging to the state's private domain. Decree 98-610 of 13 August 1998 Sécurisation Foncière Relative (SFR - Relative Tenure Security) ${ }^{3}$ specifies the procedure for delimiting the entire territory belonging to a local community (communauté de base) benefiting from a forest co-management agreement. In communities where SFR has been implemented, the commune retains the SFR plan (Article 10) and uses it to authorize new plot extensions (Article 8). The commune is the second-level arbitration body for disputes internal to the SFR if the community-based associations charged with managing the area subject to the SFR fail to reach resolution (Articles 13 and 14).

3 SFR was modeled after Ivory Coast's Plan Foncier Rural, in which communities were to map their boundaries, and then use aerial photo images to map individual plots and inventory their owners through a public land claims adjudication process. Communities who followed this process through the formal titling phase would then become the owners of the mapped land. However, few communities were able to complete the process, which was expensive and time-consuming (World Bank 2006). 
In 2001, Decree 2001-122 relating to forest management contracts for state forests was established, so as to provide a less complex process by which local communities could obtain forest management contracts (contrats de gestion forestier, CGF). Under this decree, the commune was no longer required to sign off on forest management contracts, and environmental mediators were no longer required to be involved. Dina were still identified as being integral to the contracts. However, the decree did not identify tenure security as being necessary for sustainable management and it was silent about the use of SFR as a means for the community to gain legal ownership of the land.

\subsection{Fokontany}

\subsubsection{Definition and description of fokontany}

The main decree governing the definition and responsibilities of the fokontany is Decree 2004-299 of 3 March 2004, subsequently modified in 2007. The fokontany is the basic administrative subdivision at the level of the commune: a commune thus includes several fokontany within its boundaries. Fokontany are also the basic administrative subdivision of administrative arrondissements (see Law 2014-021 concerning the representation of the State). A fokontany can be a set of hamlets, villages, sectors or neighbourhoods. The creation of a fokontany takes place by decision of the local representative of the state, from a list proposed by the mayor following a decision of the commune council. The fokontany is governed by a committee made up of a fokontany head and a deputy to the fokontany head. Decree 2004-299 (Article 3) specified that the fokontany head was selected by the commune mayor from a list of five names provided by the fokonolona. However, Decree 2007-151 of February 19, 2007 modified Decree 2004-299 to make selection of the fokontany head and a deputy the responsibility of the District Head. With that change, the fokontany became the deconcentrated administrative unit of the national government closest to local populations.

Each fokontany has a general assembly to take decisions (Decree 2004-299 of 3 March 2004). The fokontany's general assembly is made up of all inhabitants of the fokontany aged 18 and over. Decisions are taken by absolute majority and require the presence of at least half of the members over the age of 18 . The quorum is reduced to only one-fifth of members over 18 if less than half of the fokontany's members have not attended during the first two successive convocations to the general assembly.

The fokontany president, or his deputy when he is absent, is responsible for:

- Administering the fokontany in general,

- Collecting and transferring taxes to the commune,

- Calling (in writing) of the fokontany general assembly

- Drafting, and then transmitting, the general assembly's meeting minutes to the commune.

\subsubsection{Role of the fokontany in land tenure}

The roles of the fokontany with respect to land tenure are:

- Collection of property taxes, by extension of its tax collection role,

- Participation in the land committee charged with validating claims to private, untitled property. For this purpose, the fokontany head annually draws up a list of raiamandreny (elders) proposed by the inhabitants. The fokontany representatives for the land committee are chosen from this list (Article 11, Law 2006-031).

\subsection{The fokonolona}

\subsubsection{Definition and description of fokonolona}

According to the 2010 Constitution (Article 152), "The Fokonolona, organized in Fokontany within the Communes, is the basis for development and sociocultural and environmental cohesion." Other 
laws, older but still in force, define fokonolona differently. Thus, Law 2004-299 of 3 March 2004, in Article 2, speaks of the fokonolona as a subdivision of the fokontany, such as one or more hamlets or one or more villages. Law 2001-004 of 25 October 2001 relating to dina, or written community laws, gives a more nuanced definition of fokonolona, describing it as "a human, spatial community and administrative entity". Article 12 of this same law confirms the association of a fokonolona with hamlets, villages and fokontany.

Decree 2002-1170 of 9 October 2002 specified that the fokonolona was a local administrative management unit (Article 2), and that it consisted of "small urban agglomerations or rural districts, in this case hamlets, villages or islets defending the same interests, and having the habit of joining efforts to achieve common objectives". In addition, the fokonolona has a president and a vice-president (Article 20) elected by universal suffrage by members over 18. The fokontany committee oversees the election of the fokonolona committee (Article 21).

The fokonolona chooses the members of the fokontany committee (e.g., the fokontany head and his assistant) from a list of five people it proposes. This choice is made during a general assembly of the fokonolona convened by the commune mayor (Decree $\mathrm{N}^{\circ}$ 2004-299 of 3 March 2004, Article 26). According to Law 2001-004 of 25 October 2001, the fokonolona can establish a dina in a general assembly, at the scale of a hamlet, a village or a fokontany. But the dina that emerges must be approved by the commune council, the state representative, and the court respectively (Article 8).

\subsubsection{Role of the fokonolona in land tenure}

In many land tenure procedures, the fokonolona or its representatives are called upon to assist in field visits to validate ownership claims. According to Article 89, Ordinance 60-146 of 3 October 1960, a representative of the fokonolona is invited by the state land services, through the intermediary of the district head, to attend the parcel demarcation process. However, neither the fokonolona nor its representative are mentioned in Article 90 as being among the list of people attending the demarcation. The fokonolona is also summoned to attend the property rights recognition commission meetings (Article 22 of Law 60-004 of 15 February 1960). The duly summoned fokonolona also assists the commission during the on-site verification portion of the procedure for granting concessions (Article 48 of Law 60-004 of 15 February 1960 relating to the national private domain). During the procedure for determining the vocation of rural land, which is a phase in the donation application procedure, the fokonolona is only consulted if the commission in charge of the procedure deems it necessary (Decree 72-272 of 21 July 1972).

According to Article 41 of Law 97-017 of 8 August 1997, which revised the forest law, limited rights are granted to fokonolona regarding forest use. Article 41 states that "the members of the fokonolona are authorized to exercise their traditional rights of use individually or collectively in the forests of the State, of the Decentralized Territorial Collectivities, and of public establishments and private persons insofar as these rights have not already been purged".

\subsection{Legally-established groups: Vondron'olona ifotony (community-based associations)}

This section focuses on forest management associations, which are authorized to enter into comanagement contracts with the Malagasy forest service, or entities - like conservation organizations - to which it has delegated management responsibilities.

\subsubsection{Definition and description of legally-established groups}

According to Article 6 in Law 2006-031 of 24 November 2006, a legally-established group of users, like an association, can request collective recognition of rights on behalf of the occupants of private, 
untitled property. The rights can be recognized for the group as a whole or for each of its members individually (Article 8). Article 9 of the same law specifies that the request can be made by a legal representative of the group, or a deputy who has been recognized according to the bylaws of the group. A special case is the so-called "Association de communauté de base" (COBA) community-based association or, in Malagasy, Vondron'olona ifotony (VOI), created to implement the GELOSE law; it is this law that governs the transfer of management rights to renewable natural resources (see Footnote 1 for a description of the GELOSE law).

\subsubsection{Control over resources}

The VOI exercises rights of use defined in - and according to rules defined by - the Plan d'aménagement et de gestion (PAG, Development and management plan) for specific use zones. These user rights are normally authorized for all community members, however they may be subject to fees imposed by the VOI. The use rights are collective rights, since the transferred resource is not subject to individual appropriation by anyone, whether they are VOI members or not. The VOI functions as a steward of the resource for which it has management responsibilities. To enable it to carry out its responsibilities, the VOI must establish a dina which sets forth the rules governing resource use, and a policing arm to oversee the application of the dina. The VOI organizes and carries out surveillance patrols and alerts the state authorities about offenses that do not fall under its jurisdiction.

\subsubsection{Resource management tools}

The management tools that accompany the management transfer contract include the development and simplified management plan (PAG) and the dina. The use of these tools corresponds to the exercise of a management right, as conceptualized in Schlager and Ostrom's (1992) bundle of rights model. The management rights are determined through negotiations between the competent technical services and the VOI, in which they seek to reconcile the technical standards of sustainability with the needs of local communities. The GELOSE law calls for engaging an environmental mediator to assist with the negotiations, with the mediator being a person trained to ensure constructive dialogue between the two parties during the development of the management transfer contract.

\subsection{Community and land tenure}

\subsubsection{Factors that limit local communities' land rights}

Territorial collectivities and other collectives, like associations and nongovernmental organizations, have a legal status, and therefore a legal personality and thus can claim rights to resources and land. There is nothing surprising and illogical about this. However, informal local civil society collectivities do not enjoy the same benefits. In particular, the legal texts are vague when it comes to the question of whether fokonolona have a legal personality. The definitions of fokonolona in the texts are inconsistent and, at times, contradictory. Yet given the number of laws that refer to it, the framers of the legal texts clearly consider fokonolona to be an important social entity.

In its preamble, Law 2001-004 argues that one cannot ignore or do without dina, an argument which indirectly pleads in favour of fokonolona, since dina were traditionally the tool of fokonolona. Contradictions, however, appear in the definition of fokonolona or its attributes. In the definitions, the 2010 constitution suggests that the fokonolona consists of all the inhabitants of the fokontany, which is also explicitly stated in Article 2 of Decree 2004-299. However, other texts give a less rigid definition, and vary depending on the territorial or administrative division. But even these more flexible definitions, although closer to the reality on the ground, remain insufficient because they reduce or conflate the fokonolona with local authorities or administrative districts. 
Another possible interpretation of the purpose of the fokontany is that it organizes the fokonolona so that the latter complies with the state administration, which the fokontany represents, as well as with state policies and laws. Viewed from that perspective, the fokonolona could be seen simply as an administrative body ${ }^{4}$. Given the confusion over the roles and responsibilities of the fokontany and the fokonolona, logically the fokonolona cannot own or manage land or a resource, unless the land falls within the state domain.

Regarding the attributes of fokonolona, there are some important points to note, like the possibility for "the inhabitants of fokonolona" to take out collective insurance (Decree 2002-1170). One might think that this is plausible, since the fokonolona membership is delimited and it has a committee (Decree 20021170). But if that is the case, then the question of legal personality remains: how can an unincorporated entity be approved by an insurer? Although this interpretation can be called into question it is based on what is written in the legal texts, and legal texts cannot afford to give rise to such misinterpretations. In other words, as long as vagueness and potential contradictions persist around the concept of fokonolona, the latter will not be able to exercise land allocation and governance rights, because it is legally infeasible and inadvisable to assign rights to an entity that is not clearly defined.

\subsubsection{Individual rights versus collective governance}

The legal texts, whether on land tenure or related sectors, are sufficiently explicit that it is clear that legislators in Madagascar favour strengthening individual rights over strengthening collective rights. Likewise, expressions such as "collective registration", "collective development", "collective right of enjoyment" - which at first glance appear to support collective registration and abound in the texts - are misleading. They are misleading because they give the incorrect impression that they relate to genuinely collective uses, which are subject to collective governance. In most cases, however, they refer to the rights of individuals to individual plots.

The use of such misleading expressions is detrimental to the concept of collective use rights, a term which appears only rarely in texts. In terms of securing rights, the texts favour registration, which they see as the ideal. An assertion like, "collective use excludes registration in the name of beneficiaries" (Article 54, Law 60-004) suggests that the writers of the law felt some disdain towards these collective uses; uses which nevertheless exist. And lacking entirely from the laws is support for the spontaneous, customary local organization and governance around these so-called collective uses. Even the GELOSE law, which is currently the only law which recognizes the right of local communities to manage resources, relies on the model of a community association with legal personality, a concept which should not be confused with a real local community.

\subsection{Legal texts cited}

\begin{tabular}{ll}
\hline $\begin{array}{l}\text { Constitution de la IVe République du Madagascar. } 11 \\
\text { decembre } 2010\end{array}$ & $\begin{array}{l}\text { Constitution of the 4th Republic of Madagascar, } \\
\text { December 11, 2010 }\end{array}$ \\
\hline $\begin{array}{l}\text { Loi no } 60-004 \text { du } 15 \text { février } 1960 \text { relatif au domaine } \\
\text { privé national }\end{array}$ & $\begin{array}{l}\text { Law 60-004 of February 15, 1960 concerning the } \\
\text { national private domain }\end{array}$ \\
\hline $\begin{array}{l}\text { Loi no } 93-005 \text { du } 26 \text { janvier } 1994 \text { portant orientation } \\
\text { de la politique de décentralisation, modifiée par la Loi }\end{array}$ & $\begin{array}{l}\text { Law 93-005 of January 1994 on the direction of } \\
\text { decentralization policy modified by law 94-039 of }\end{array}$ \\
$\mathrm{n}^{\circ}$ 94-039 du 3 Janvier 1995, et la Loi no $2004-001$ du \\
\begin{tabular}{l} 
17 Juin 2004 \\
\hline
\end{tabular}
\end{tabular}

4 The fokonolona chooses five members to run for the fokontany election, whereas the fokontany committee oversees the election of the president of the fokonolona. 
Loi no 94-008 du 26 avril 1995 fixant les règles relatives à l'organisation, au fonctionnement et aux attributions des CTD [collectivités territoriales décentralisées]

Loi no $96-025$ du 30 septembre 1996 relative à la gestion locale des ressources naturelles renouvelables

Loi no $97-017$ du 8 août 1997 portant révision de la législation forestière

Loi no 2001-004 du 25 octobre 2001 portant réglementation générale des Dina en matière de sécurité publique

Loi n ${ }^{\circ} 2004-001$ du 17 juin 2004 relative aux Régions

Loi ${ }^{\circ} 2005-019$ du 17 octobre 2005 fixant les principes régissant les statuts des terres

Loi n ${ }^{\circ}$ 2006-031 du 24 novembre 2006 fixant le régime juridique de la propriété foncière privée non titrée

Loi n ${ }^{\circ}$ 2014-021 du 12 septembre 2014 relative à la représentation de l'Etat

Loi organique $\mathrm{n}^{\circ} 2014-018 \mathrm{du} 12$ septembre

2014 régissant les compétences, les modalités d'organisation et de fonctionnement des Collectivités territoriales décentralisées, ainsi que celles de la gestion de leurs propres affaires

Décret $\mathrm{n}^{\circ} 72-272$ du 21 juillet 1972 portant sur le classement en zones à vocations forestières, pastorales ou agricoles des terres de Madagascar

Décret $n^{\circ}$ 98-610 du 13 août 1998 règlementant les modalités de la mise en œuvre de la Sécurisation Foncière Relative

Décret $n^{\circ}$ 2001-122 du 14 février 2001 fixant les conditions de mise en œuvre de la gestion contractualisée des forêts de l'Etat

Décret $n^{\circ} 2002-1170$ du 9 octobre 2002 fixant les règles relatives à l'organisation, au fonctionnement et aux attributions du Fokontany et du Fokonolona

Décret $n^{\circ}$ 2004-299 du 3 mars 2004 fixant l'organisation, le fonctionnement et les attributions du Fokontany

Décret n ${ }^{\circ}$ 2007-151 du 19 février 2007 modifiant certaines dispositions du Décret $\mathrm{n}^{\circ}$ 2004-299 du 3 mars 2004 fixant l'organisation, le fonctionnement et les attributions du Fokontany

Ordonnance $\mathrm{n}^{\circ} 60-146 \mathrm{du} 3$ octobre 1960 relative au régime foncier de l'immatriculation

Ordonnance $\mathrm{n}^{\circ}$ 62-123 du 1 octobre 1962 sur la vocation des terres rurales

Ordonnance $\mathrm{n}^{0}$ 73-073 portant orientation $\mathrm{du}$ développement rural

Ordonnance $\mathrm{n}^{\circ}$ 74-021 portant refonte de l'ordonnance $\mathrm{n}^{\circ} 62-110 \mathrm{du}$ 1er octobre 1962 sanctionnant l'abus de droit de propriété et prononçant le transfert à l'Etat des propriétés non exploitées.
Law 94-008 establishing the rules relating to the organization, functioning, and competencies of the decentralized territorial collectivities

Law 96-025 of September 30, 1996 concerning local management of renewable natural resources

Law 97-017 of August 8, 1997 on forest law reform

Law 2001-004 of October 2001 on the general regulations of Dina dealing with public security

Law 2004-001 of June 17, 2004 concerning the regions

Law 2005-019 of October 17, 2005 establishing the principles for categories of land

Law 2006-031 of November 24, 2006 establishing the legal status of untitled private property

Law 2014-021 of September 12, 2014 concerning the State's representation

Organic law 2014-018 of September 12, 2014

establishing the competencies, modes of organization and functioning of the decentralized territorial collectivities as well as those for managing their affairs

Decree $72-272$ of July 21, 1972 on the classification of forest, pastoralist, or farm zones for land in Madagascar

Decree 98-610 of August 1998 regulating the implementation of Relative Tenure Security

Decree 2001-122 of February 14, 2001 establishing the conditions for implementing management contracts for state forests

Decree 2002-1170 of October 9, 2002 establishing the rules regarding the organization, functions, and competences of the Fokontany and Fokonolona

Decree 2004-299 of March 3, 2004 establishing the organization, functions, and competences of the Fokontany

Decree 2007-151 of February 19, 2007 modifying certain provisions of Decree 2004-299 of March 3, 2004 establishing the organization, functions, and competences of the Fokontany

Order 60-146 of October 1960 concerning land titling

Order 62-123 of October 1, 1962 on rural land use

Order 73-073 on the direction of rural development

Order 74-021 on the reform of Order 62-110 of

October 1,1962 sanctioning the abuse of property

rights and imposing the transferral of unused land to the state 


\section{Key themes in local-level land governance in Madagascar}

\subsection{Introduction}

An extensive literature on customary land tenure and governance exists for Madagascar, much of it based on ethnographic and geographical research supported by France's Institut de Recherche pour le Développement (IRD) (formerly Office de la Recherche Scientifique et Technique Outre-mer (ORSTOM) from the 1960s onwards. ${ }^{5}$ To keep the scope of our review manageable, we focused primarily on studies published after 1990 and that included at least some discussion of governance and tenure issues related to collectively managed lands or resources, like cattle pastures and forests. We reviewed studies from multiple regions so as to encompass a range of customary tenure systems, production systems and ecosystems present in Madagascar. We included studies of tenure systems more generally, as well as those in areas where villages have entered into co-management arrangements for national parks, special reserves, classified forests, and forests and pasture lands categorized as public domain lands. Figure 2 (at the end of the report) shows Madagascar's 22 regions and Figure 3 shows the locations of a selected sample of studies. Our review is by no means a comprehensive review of research on customary governance and tenure in Madagascar, but it aims to provide the reader with a sense of the similarities and variability in governance and tenure systems across the island.

\subsection{Legal pluralism: Intersecting state and customary tenure and governance systems}

Governance arrangements in rural Madagascar are characterized by legal pluralism, with state and customary legal systems operating simultaneously (Boué and Colin 2018). However, legal pluralism does not mean that the state and customary systems operate independently of each other. Rather, legal pluralism in Madagascar consists of a hybrid of state and customary systems (Boué and Colin 2018; Valkonen 2018; Di Roberto 2020). The forest co-management contracts authorized under the 1996 GELOSE law are examples of hybrid systems, in which customary rules may regulate access to forest products, provided that they do not violate national laws or policies (Henkels 2002). Other examples are more ad-hoc, like land sales that do not follow formal state procedures for registration of land transactions, but are recorded through written documents signed and stamped by local-level officials (e.g., the fokontany president and/or commune mayor) (Di Roberto 2020). In Madagascar, customary law has traditionally been, and in some areas continues to be, transmitted orally. However, written documentation for land transactions (Boué and Colin 2018; Di Roberto 2020) and codification of local community bylaws governing forest resources is increasingly the norm (Henkels 2002).

The relationship between state and traditional authorities in rural Madagascar is complex and characterized by mutual interdependence. Traditional authorities may require support from state agents, particularly when they wish to apply local laws restricting the use of forest or rangeland resources to outsiders (Horning 2004). Such support is not always forthcoming. Muttenzer (2006) documents a case in Boeny Region in northwest Madagascar where villagers' efforts to prevent outsiders from converting portions of their sacred forest to agricultural fields have been stymied by the refusal of state agents to enforce the prohibition on forest clearing. Conversely, representatives

5 For an overview of research produced via ORSTOM/IRD up to the early 2000s, see Feller and Sandron (2010). 


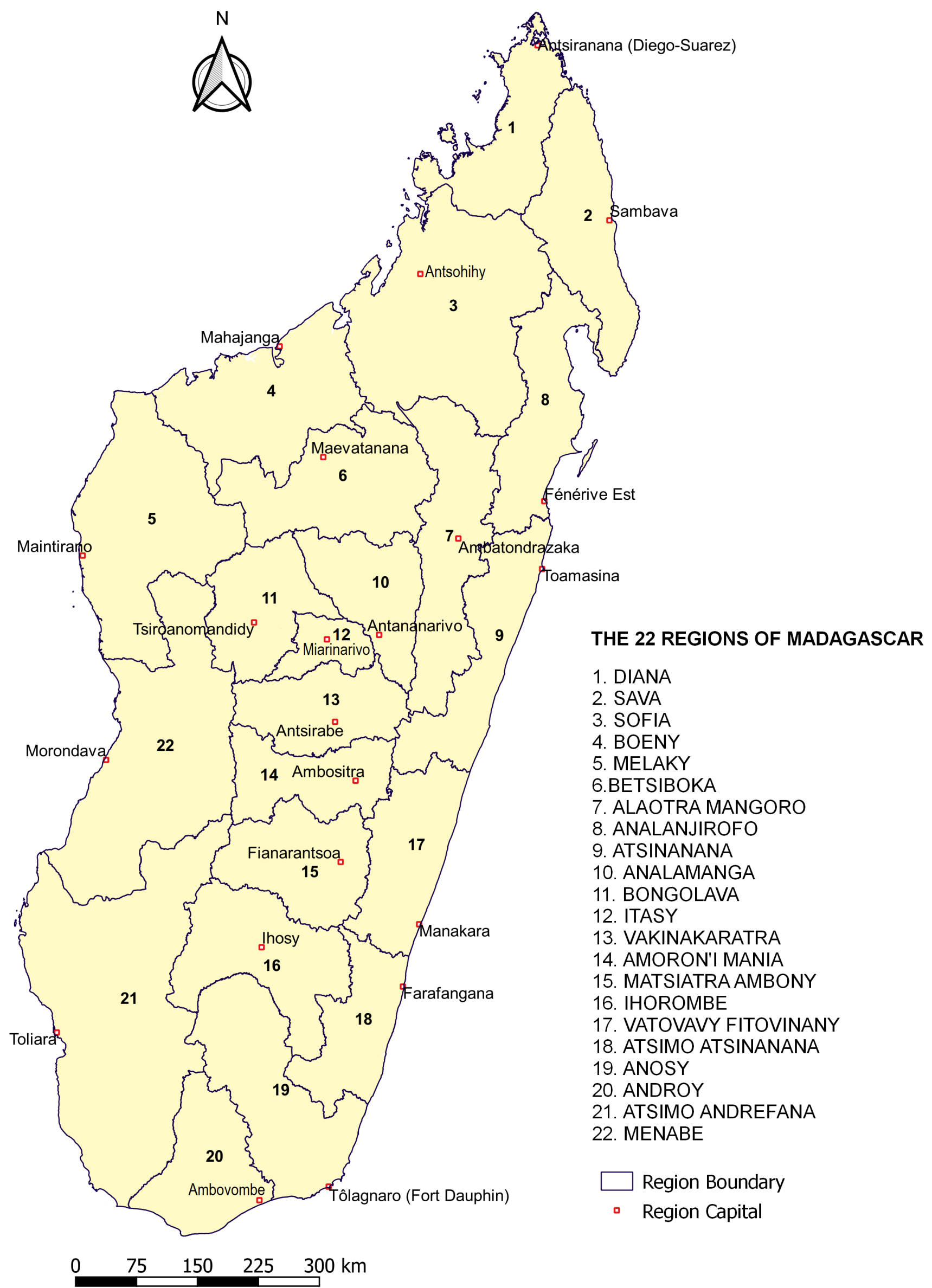

Figure 2. Regions of Madagascar 


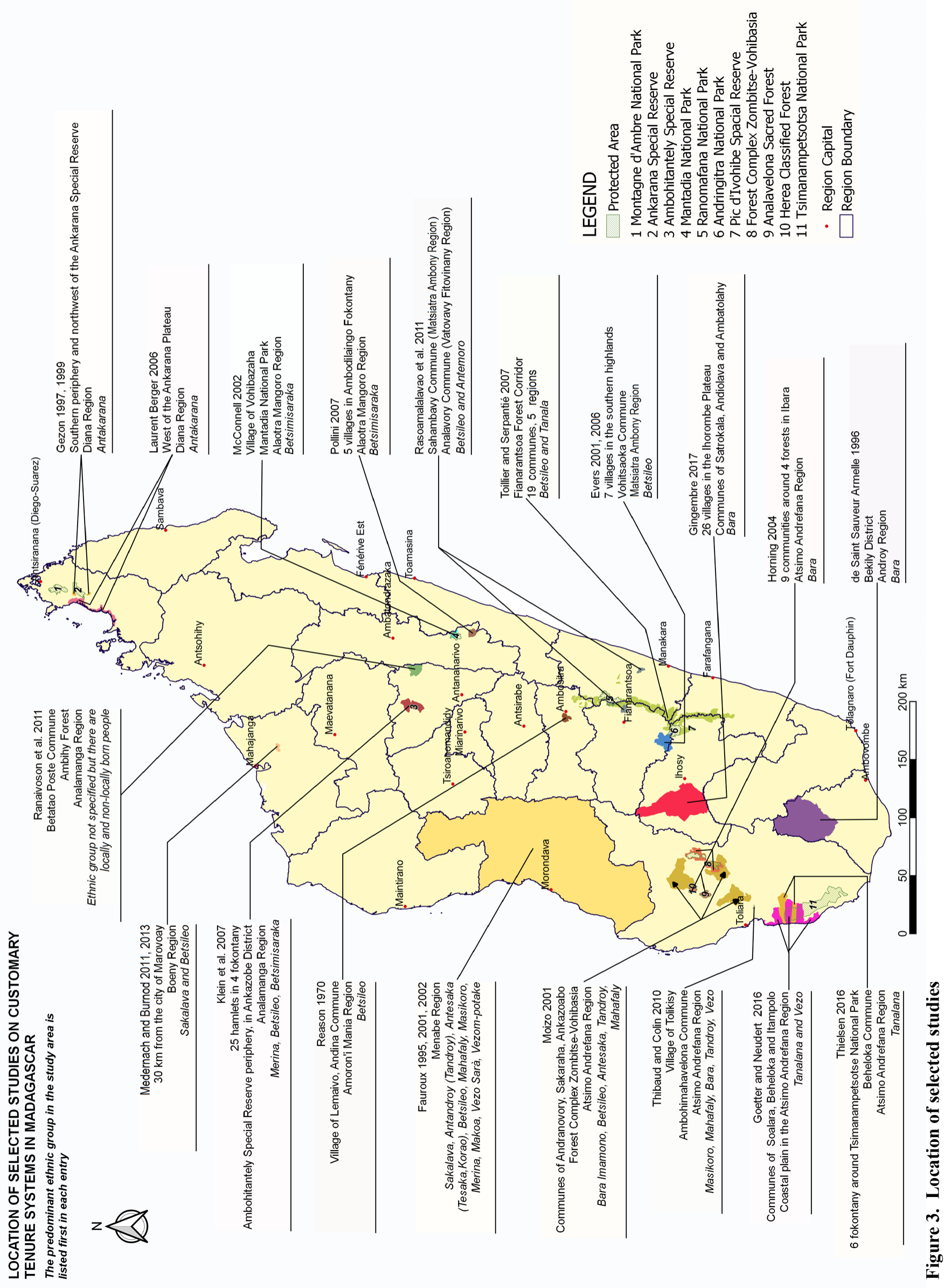


of the state may need the backing of traditional leaders when issuing land concessions for large-scale agricultural or forestry developments, mining or logging. Gingembre's 2017 study of the politics surrounding an investment company's efforts to acquire a long-term lease for land on the Ihorombre Plateau illustrates the degree to which state and village authorities (known as lonaky) work together to further their interests. She states,

"While mayors [of the communes] may gain in legitimacy by being close to respected local leaders, lonaky usually need support from state agents to exert influence on external affairs. In this relationship of interdependence, the balance can vary from one case to the other."

(Gingembre 2017:40)

Where traditional authorities retain local legitimacy, they often function as intermediaries between community members and outside authorities (Evers 2001; Horning 2004; Gingembre 2017; Di Roberto 2020). However, in their role as brokers, traditional authorities sometimes act in ways that further their own political and economic interests, rather than working for the benefit of the broader community (Blanc-Pamard and Fauroux 2004; Berger 2006; Gingembre 2017).

Support from traditional authorities can smooth the way for international conservation organizations, like Worldwide Fund or Conservation International, to whom the state has delegated management authorities when it comes to national parks or protected areas. Berger (2006) reported that WWF was able to achieve some success in reducing deforestation in a protected area on the Ankarana Plateau in northern Madagascar by working through the king (ampanjaka) of the Antankaranana, the dominant ethnic group, to promote the project. In some areas, lines between the state and customary systems become so blurred that it is difficult to distinguish the two. This is the case on the Ankarana Plateau and adjacent coastal areas, where the Antankaranana monarchy was reorganized into an association with legal status in the 1990s (Berger 2006). The association's role consists of protecting and preserving sacred spaces, educating the younger generation in Antankaranana customs and culture, and protecting the environment. The association was organized around the administrative structure of the fokontany and membership was opened to both recent and long-term migrants, allowing them to take part in decision making about land issues, a role from which they had previously been excluded. Berger (2006) argues that the association essentially replaced the monarchy with a centralized democratic body of royal agents who represent the state.

\subsection{Local customary governance}

Local customary governance systems in Madagascar vary depending upon which ethnic group ${ }^{6}$ is or was historically dominant in a region, as well as upon the extent to which that group has been able to retain its traditional authority in the face of pressures from the state, in-migration, and cultural change linked to structural transformation in local economies (c.f. 2001, 2002; Moizo 2001; Thibaud 2010). Madagascar has 18 officially recognized ethnic categories (Table 1) (Covell 1987, cited in Sharp 1993), each with its own land governance and tenure system. ${ }^{7}$ Some sources treat the Mikea and Vezo as distinct ethnic groups while others consider them to be subgroups of the Sakalava (Sharp 1993).

6 In northern Madagascar, the term karazaña is used to refer to one's "ethnicity" (Brown 2004) but can also refer to one's clan (Lambek and Walsh 1997).

7 Southall (1971) noted that most of the names given to the different ethnic groups in Madagascar were given by foreigners, and many of the names correspond to ecological descriptions of the areas where various groups were dominant at the time of colonization. For example, Tanala = people of the forest; Androy = people of the thorn bush; Tanosy = people of the island; Ankarana $=$ people of the rocks; and Sakalava = people of the long valley. Given that all of the groups speak a variant of Malagasy, Southall argues that they might better be considered regional groupings with particular adaptive approaches to the ecosystems in which they resided, rather than ethnic groups. A recent linguistic study by Serva and Pasquini (2020) lends support to his argument regarding regional groupings rather than ethnic groups. 
Table 1. Ethnic groups of Madagascar

\begin{tabular}{lll}
\hline Antaifasy & Antanosy & Makoa (Masombika) \\
Antaimoro & Bara & Merina \\
Antaisaka & Benzanozano & Sakalava \\
Antakarana & Betsileo & Sihanaka \\
Antambahoaka & Betsimisaraka & Tanala \\
Antandroy (Tandroy) & Mahafaly & Tsimihety \\
\hline
\end{tabular}

Ethnic affiliation is important with respect to land tenure, as it can be used as justification to either exclude or to include others in access to land and resources. Lineage and clan membership generally play a key role in who can allocate land, who has access to land and under what conditions, how and who can make decisions about land, and how rules regarding land and resource use are enforced.

\subsubsection{Clan: Cultural and religious leadership}

Clans $^{8}$ are composed of individuals or families who claim a common ancestor, either real or symbolic (Barry et al. 2000). The founding clan of a territory is composed of the families who initially settled the area. Clans share a name or symbol, fady (taboos, called faly in some areas), and oral histories. Mutual support, protection and hospitality are expected among clan members. The clan leader, usually an older male, is a religious authority and functions as an intermediary between humans and spirits. His roles may include performing ceremonies, resolving conflicts, and reprimanding incorrect social behaviour. In areas with sacred forests, the clan leader is charged with managing them; he also can play an important role in influencing local attitudes toward protected forests (c.f., Gezon 1997, 1999; Berger 2006).

\subsubsection{Lineage: Socio-political organization and governance}

A lineage consists of descendants of a common relative, with each member being able to trace his or her ancestry back to that relative (Barry et al. 2000). In much of rural Madagascar, the lineage forms the basic unit for social and political organization. Generally, the head of the lineage, usually the oldest male member, sets the rules-in-use for lands held at the lineage level. If a lineage is subdivided, governance responsibilities are managed at the sublineage level. Village-level political authorities often consist of the heads of the lineages present in the village. In most areas, the lineage heads are referred to as rey amin'dreny, literally meaning 'parents', but which is better translated as village elders in English. In some communities, only heads of founding families or lineages are considered rey amin'dreny. Founding families are typically referred to as tompon-tany, or 'masters of the land'. ${ }^{10}$ The tompon-tany, led by their eldest members, have general jurisdiction over the lands they and their ancestors have cleared, as well as any remaining undeveloped land. Box 1 provides examples of the variation that occurs within in Madagascar in this generalized land governance structure.

8 The information for clans and lineages included in the following sections is drawn from multiple sources reviewed for this report. Some variation exists, depending on the ethnic group and socioecological context, but the general pattern for clans and lineages applies across the island.

9 In Ibara, village elders are referred to as olobe or mpitakazomanga (Horning 2004).

10 In his research in northern Madagascar in Antankarana communities, Walsh (2002:457) emphasizes the notion of responsibility for the land that is implied in the term tompon-tany: "[B]eing tompontany means acting responsibly on the land from which one makes one's livelihood. Indeed, in recognition of the myriad meanings of the Malagasy term tompo, we might think of tompontany as people 'responsible to/for the land'. It is important to understand, however, that, to many, being responsible to and for the land in Ankarana is tantamount to being responsible to and for royal authority." 


\section{Box 1. Examples of land governance structures}

Ambohitantely Special Reserve peripheral zone (Klein et al. 2007): In hamlets that comprise the 'peripheral zone' east of the Ambohitantely Special Reserve north of Antananarivo, social organization is based on the caste system of the original Merina settlers. Leaders in this area serve a hybrid role as elders and traditional leaders. The tarika, the traditional term used to designate the family, includes all persons that have a shared tomb (i.e, common ancestor). The tarika chief occupies a position of high social prestige and exercises considerable power at the local level. Responsibilities of the tarika chief range from conflict resolution to the organization of traditional ceremonies and rituals. Decisions made by the commune without involving the tarika chief are likely to encounter noncompliance or resistance from other community members. The fokonolona is composed of the chiefs of the different tarikas. Tarikas are organized into companies based on traditional ties created through a blood-mixing ritual and marriage alliances. Companies provide mutual assistance for activities requiring a reliable labour supply, like cattle guarding and rice planting.

Vohibazaha (McConnell 2002): In the Betsimisaraka community of Vohibazaha near Mantadia National Park, land governance is centred around family tombs. Land is managed in concentric circles, which are progressively less strictly managed as one moves outward from the family tombs. Land management is led by the lineage/clan heads (tangalamena), who also ensure compliance with sacred rules. The Vohibazaha community includes many lineages. The lineage heads serve both as political and land governance decision makers as well as being religious and cultural leaders, thereby blurring the distinction between lineage and clan leadership and between nuclear and extended families/lineages. Leadership in this community consists of an aggregated group of the 12 lineage leaders who together manage three main areas centred around seven tombs.

Tsimanampesotse National Park (Thielsen 2016): In the fokontany at the north end of Tsimanampesotse National Park in southwestern Madagascar, the local Tanalana use the term fokonolo rather than fokonolona. The fokonolo can be thought of as "all people who meet at a moment to take a decision." It takes one of two forms: 1) clan/lineage fokonolona identity: this is the case when the fokonolo is a convened by the traditional chief or elders and includes representatives of a lineage or clan, who may live in one or more fokontany; or 2) fokontany fokonolo identity: this is the case when the fokonolo is convened by the fokontany president and includes representatives from within the fokontany administrative territory. The fokonolo convened by the fokontany may involve multiple ethnic groups, clans and lineages. Neither fokonolo is democratic; elders make the decisions beforehand. Lilin-draza (rules of the ancestors), which prescribe rituals and duties vis-à-vis the supernatural beings, elders and society, continue to form the basis of Tanalana governance in and around Tsimanapesotse National Park.

Numerous studies underline the importance that the placement of family tombs plays for Malagasy societies in establishing rights to land by giving it the status of ancestral land (tanindrazana) (c.f., Ottino 1998; Evers 2006; Di Roberto 2020). In his study of the links between kinship, alliances and patrimony, Ottino (1998) found that throughout Madagascar, a common theme was that kinship cannot be disassociated from landholdings, with the family tomb serving as the anchoring point of kinship ties. However, it is not just any land that is important, but rather ancestral land that has been transmitted through inheritance and which the holders have the responsibility to keep intact or expand so that they can pass it on to their heirs.

Di Roberto (2020) found that among the Merina in the Central Highlands, kinship relations are based on common ties to ancestral land rather than on sharing a common lineage. For persons who do not share a common ancestor, kinship relations are created through marriage or blood pacts (fatidra) (Di Roberto 2020). Di Roberto identified four levels at which it is important to understand tenure rights and responsibilities among the Merina at Ambatomena (Vanikaranatra Region): the household (tokantrano), the "small family" (mpianakavy), the co-heirs (mpiara mandova), and the group responsible for ensuring that social obligations are met (mpiaray adidy/mpiara mitrondra). The household consists of 
the nuclear family members who reside in the same house; the "small family" consists of the nuclear family and their children, whether they live in the same house or not. The co-heirs are persons who have inherited a common piece of land. The eldest male in the line of succession has the most authority over land held in common, but generally assigns specific parcels to each of the co-heirs. The group of coresponsibles are those persons who share family obligations vis-à-vis honouring the ancestors and who have joint responsibility for ensuring that the group's patrimony remains intact. The eldest male of the co-responsibles ensures that social cohesion (fihavanana) is maintained between family members, and he must be consulted before family members can sell their land.

The rey amin'dreny usually are the key decision makers in the fokonolona, the state-sanctioned but locally legitimate village council that governs at the level of the fokontany. In a study of whose voices counted in decisions about whether to allocate community land to large-scale land concessions on the Ihorombe Plateau located in the Southern Highlands, Gingembre (2017) concluded that who has 'voice' in community decisions varies by location, and those who do have a voice in decision making are often not representative of the entire community. She found that older men tended to control the vote in the fokonolona. Decisions were often made by key elders (i.e., typically male heads of lineages or founding families) behind closed doors prior to community meetings. In such cases, community meetings became a formality, where policy and rules were proclaimed rather than discussed and voted on.

In their essay, 'L'illusion participative' (the illusion of participation), Blanc-Pamard and Fauroux (2004) point out the non-egalitarian reality of traditional decision-making bodies in western Madagascar, noting that they are rarely democratic in how they function, privileging those with higher social status and greater wealth. They also argue that lineage-based decision-making bodies in western Madagascar have proved ill-suited to managing issues that extend beyond the lineage's jurisdiction. At the same time, lineage leaders have recognized that it is in their interest to put on a show of democratic participation as a means of attracting funding from international donor agencies, who emphasize the need for participatory development processes. Blanc-Pamard and Fauroux (2004) conclude that there is hope that the illusion of participation will transform into meaningful participation as a wider range of villagers becomes more used to participating actively in meetings.

\subsubsection{Land conflicts and conflict management}

In rural Malagasy communities, causes of land conflicts include ambiguity over land ownership within the family (Raison 1991), conflicting claims between established occupants and recent migrants (Fauroux 2001; Moizo 2001), and competition between herding and farming needs (Gezon 1999), among others. Land conflicts may also occur between local communities and the state (Pollini 2007); between communities and conservation NGOs (Gezon 1997, 1999; Horning 2004) who often have been delegated authorities to manage state lands; or between communities and outside investors (Medernach and Burnod 2013). Conflicts can split entire villages. In one village near the Ambohitantely Special Reserve, a conflict over land rights going back to colonial times has divided the villagers along ancestral lines (Klein et al. 2007). Conflicts also occur between villages. In Marovoay, Medernach and Burnod (2013) describe a conflict that arose when outsider investors, failed to to first consult with the neighboring Sakalava villagers before negotiating concessions for jatropha plantations with Betsileo rice farmers. The Sakalava were particularly incensed because, not only was land where they grazed their cattle affected, they also claimed founding-family privileges for the land occupied by the Betsileo, and thus felt that they should have been the ones to do the negotiations.

No discussion on land conflicts in Madagascar would be complete without mention of the Malagasy concept of fihavanana. Malagasy society places a high value on fihavanana ${ }^{11}$, which often translated

11 The concept of fihavanana appears to have its origins in Merina society, but has been adopted as a guiding social principle throughout much of Madagascar. It is thought to be derived from the root word, 'havana' meaning relation. A similar concept, filongoa, is found in southern Madagascar among the Bara (Scheidecker 2016). However, Scheidecker reports that among the Bara, filongoa applies more narrowly, and encompasses primarily patrilineal kin. 
as solidarity (Kneitz 2016). Fihavanana emphasizes maintaining peaceful relations, both with kin and neighbours (Kneitz 2016). Consequently, rural Malagasy generally seek to first manage conflicts over land and natural resources at the family or lineage level (Gezon 1999; Di Roberto 2020). If the conflict cannot be resolved at that level, or if it involves multiple families or lineages, the disputing parties take the case to the fokonolona, where the rey-mandreny function as both mediator and judge (Gezon 1999). An important feature of conflict resolution on the part of the fokonolona is that it focuses more on reconciling the quarrelling parties and preserving social relationships, and less on assigning fault to a particular party (Rosés 2016).

Gezon's (1999) description of village-level conflict resolution near the Ankarana Special Reserve highlights the importance that the fokonolona places on reconciliation.

"Village settlements operate on the basis of cooperation (fiarana) and consensus. The primary goal of the fokonolona, according to the elders, is to establish positive relations between the disputing parties by acting as a mediator. Discerning right (ny mariny) and wrong is also important, and the fokonolona often goes to great lengths to get as much evidence as possible. But setting relationships straight (mandaminy) is the elders' first stated objective" (Gezon 1999:86).

Only if the fokonolona cannot resolve the conflict, can the disputants take a case to a state court (Gezon 1999; Di Roberto 2020). However, very few cases are taken to the state authorities (fanjakana). Not only does taking a case to a state court involve an outlay of large sums of money, but also the judges in state courts typically do not know the history of the situations brought before them (Gezon 1999; Di Roberto 2020). Equally important, the state courts do not operate based on the principle of seeking consensus or voluntary cooperation, both of which, in the eyes of rural Malagasy, are necessary for legitimacy (Kneitz 2016). Although use of the principle of fihavanana tends to diminish the likelihood of injured parties pursuing vengeance, as Sandron (2016) points out, it is often far from egalitarian in its application, and tends to reinforce existing social inequities and power imbalances.

\subsection{Dina: Where customary and state law meet}

A key feature of customary land governance systems in Madagascar is the widespread reliance on dina - social codes that govern social interactions at the local level, including natural resource access and use. Although traditional in their origin, dina are recognized as legally valid under state law (Karpe et al. 2007). Karpe et al. (2007) describe dina as agreements made by members of a community (i.e., the fokonolona) in which each person indicates their agreement through an oath, and where fines or sanctions (vonodina) are envisioned or applied to those who don't respect the agreed upon terms. Traditionally, a dina is adopted by the fokonolona and then consecrated through a ritual. The ritual makes clear to participants that, in addition to being an agreement between community members, the dina also is a pact with Zanahary (God), the ancestors, and spirits of the locale (Karpe et al. 2007). Dina were (and often still are) oral voluntary agreements that have the force of law for members of the community that creates them. However, increasingly the fokonolona are developing written dina, which are

\section{Box 2. Dina in Ambodilaingo (Beforona Commune)}

In Ambodilaingo, the village council which is composed of elders from each of the lineages present in the village collaborates with state administrators to create local bylaws, known as dina. Although often unwritten, dina that the community considers to be very important are written up and registered at the commune. This puts the community in a much stronger legal position in case of disputes. The dina define rules of behaviour, what constitute offenses, and punishments in cases where the rules are violated. Examples of behaviours that are the object of dina in Ambodilaingo include the lighting of uncontrolled fires, crop thefts and taboo violations (Pollini 2007). 
then registered either with the fokontany or the commune (see Box 2). Dina are the chief means by which customary forest governance systems in Madagascar have regulated access to and use of forest resources (Fritz-Vietta 2015).

\subsection{Customary land rights}

Who is considered a community member and, therefore, who has rights to land and resources, as well as the nature of those rights, differs by ethnic group and by geographic location. As a rule, persons who belong to founding lineages, clans or families, and who remain in the community, have access to land by virtue of their membership in the founding group (c.f., Fauroux 2001; Moizo 2001; Di Roberto 2020). Community members can acquire land in a variety of ways including through inheritance, clearing of unoccupied land, sharecropping, intergenerational gifts, borrowing, rentals and purchase (Gezon 1997; Jones et al. 2018; Di Roberto 2020). Southall (1971:160) describes Malagasy kinship systems as "variants on a cognatic model, with a range of emphasis on patrifiliation". He reports that patrilineal descent is more common among ethnic groups with greater dependence on extensive cattle raising, like the Sakalava and Tsimihety, whereas bilateral descent is more common among those groups with greater reliance on paddy rice cultivation, like the Betsileo and Merina. Whether a group traces descent patrilineally, matrilineally or ambilineally affects not only who inherits land, but also who exercises control over lineage and clan lands.

In Bevary, near the Ankarana Special Reserve (northern Madagascar), land-use rights are inherited by both sons and daughters in landowning families (Gezon 1997). If there are too many heirs, they inherit on a rotating basis. Gezon (1997) reported that land rentals were common in Bevary, and, although rare, land sales did occur. In Vakinankaratra Region (Central Highlands), Di Roberto (2020) documented three ways in which rights to land were commonly transferred to relatives: inheritances (l'héritage), gifts (la donation) and delegation of rights (la délégation de droits). Other ways in which residents of Vakinankaratra Region gained access to land included sharecropping, rentals and land purchases. However, land purchases were relatively rare and most occurred between family members. Although illegal, sharecropping is a common means by which people acquire access to land in many areas (c.f., Jarosz 1991; Evers 2001; Scales 2011). Although sharecropping in land is often thought of as a means by which the landless and the poor gain access to land, it is also a means by which betteroff farmers, who can afford to hire labour to work the land, can expand their production (Jarosz 1991).

In-migrants, whether their families have been in the area for generations or more recently arrived, must get approval from the tompon-tany to clear land (Fauroux 2001; Moizo 2001; Jones et al. 2018). The process for a migrant to get such approval may take some time. In his study of forest uses in Manongarivo (northern Madagascar), Ranjatson (2011) described a lengthy social legitimation process for migrants before they were allowed to clear a new forest. To gain access to land, a new migrant had to first borrow parcels from a host family and could only grow annual crops like cassava or rice. Only after the migrant had spent several years farming on borrowed parcels, would the tompon-tany allow him to clear his own land.

As land becomes scarcer, the rules governing how newcomers can gain access to land may change. Thibaud and Colin (2010) reported that prior to the 1990s, male migrants in Masikoro-dominated communities near Toliara could easily acquire land initially through share-cropping arrangements. If they married into the community, they could obtain permission to clear land. As the migrants became wealthier, they began to purchase land. By the mid-1990s, however, when land had become scarce, as a means to slow down the rate of forest clearing, the tompon-tany decided to charge migrants a fee for the right to settle in the area and clear land. More recent migrants no longer can get permission to clear land and have access to land only through short-term borrowing arrangements. Evers (2001 2006) documents a similar situation with respect to lowland rice fields in the Southern Highlands, where in 1967, the founding families - most of whom had settled in the area during the 1950s and 1960s divided up all the unclaimed fertile bottom land among themselves and made a pact that they would only lease, and not sell land to newcomers. 
Various avenues exist by which migrants can become socially integrated into the community, with two common pathways being by marrying a community member or through blood-mixing ceremonies (fatidra) (Gezon 1997; Fauroux 2001; Jones et al. 2018; Di Roberto 2020). However, the nature of the rights granted through such relationships varies. Among the Antakarana living near the Ankarana Special Reserve in northern Madagascar, newcomers who go through fatidra acquire the right to access land in the community's territory. However, such ties do not extend to granting inheritance rights for the newcomer's offspring (Gezon 1997). Among the Sakalava in Menabe Region, a migrant also could acquire membership in the community through marriage or fatidra, but the rights he could acquire to land were limited to use rights, were always subject to revocation, and placed him into a long-term relationship of dependency vis-à-vis the tompon-tany from whom he acquired land rights (Fauroux 2001).

\subsection{Women's land rights}

Madagascar's national laws governing women's land rights emphasize gender equality, albeit with some important gaps. The 2010 Constitution specifies that all individuals are equal with respect to rights and enjoy the same fundamental liberties that are protected by law, regardless of sex, age, education, wealth, religion or opinion. The law on succession also treats male and female surviving spouses equally. ${ }^{12}$ Whether male or female, spouses do not inherit from each other, but rather the order of inheritance is: children, grandchildren, father and mother, brothers and sisters, uncles and aunts, first cousins, and then the surviving spouse. Although male and female heirs inherit equally, the co-heirs can agree that female heirs will be given money in lieu of land. Under the 2007 marriage law, ${ }^{13}$ property held in common is supposed to be divided equally between the husband and wife upon the dissolution of a marriage. However, Widman and Hart (2019) noted that this clause is often not followed, and more commonly the traditional division (known as kitay telo an-dalana) allocates twothirds to the husband and one-third to the wife.

At best, most of the studies we reviewed provided only a sketchy description of women's rights to land or forest resources under customary tenure systems. From the limited evidence available, it appears that women's rights to land vary considerably by ethnic group, but in general their rights are weak. However, in some areas, like the Central Highlands, women's rights appear to be becoming stronger in response to changes in socioeconomic conditions and growing awareness of state laws supportive of gender equality in land rights (Di Roberto 2020). The following examples, drawn from various parts of Madagascar, illustrate some of the common patterns in women's land rights, as well as some key differences, across ethnic groups.

In Ambatomena (Vakinankaratra Region), where Merina were the dominant ethnic group, Di Roberto (2020) reported that traditionally only men inherited land. However, along with their inheritance comes the obligation to maintain the land in the family and contribute toward the famadihana ritual ${ }^{14}$, a generally costly affair. Di Roberto also found that over time, women in Ambatomena have become increasingly likely to inherit land. Widows in Ambatomena retained decision-making power over land that their husbands inherited, as well as any land that the couple acquired together while married.

Also among the Merina, in another site within Vakinankaratra Region, Valkonen (2018) found that inheritance was patrilineal and daughters would inherit less land, if any, than sons. Sometimes daughters would be given small parcels by their parents. However, because women either didn't inherit

12 Loi n68-012 du 4 juillet 1968 relative aux successions, testaments et donations

13 La loi $n^{\circ} 2007-022$ du 20 août 2007 relative au mariage et aux régimes matrimoniaux

14 Famadihana, often translated as "the turning of the bones" is a funeral ritual in the Highlands that involves exhumation and then reburial of the bodies in the family tomb. The ritual takes place every 5, 7 or 9 years, and involves all or some of the descendants of the founding ancestor (Di Roberto 2020). 
or only got small parcels, this absolved them from having to contribute toward family festivities which could be quite expensive. Valkonen (2018) emphasized that the rules were not fixed, and some people gave equal amounts to all heirs. The following quote from Valkonen $(2018: 182)$ illustrates how the security of one's claims to land depends to a great extent upon the quality of relationships between family members.

"Social differences exist, and pressure can be put on family members and their tenure rights questioned. A lot thus depends on the quality of relationships. If tensions and misunderstandings emerge, some members might see their parcels taken away or their rights contested, placing them in a situation of insecurity. Siblings who have moved away from the zone (absentee owners), children who have not been officially recognised as descendants of their parents, younger siblings and divorced or widowed women are particularly vulnerable."

Among the Betsileo in the Southern Highlands, Evers (2001) found that inheritance was patrilineal, with land being equally divided among the sons. Only in very rare cases did women inherit land when their parents died. However, in cases where the daughter remained in the area after marriage (i.e., if she married someone from within the region), she could have use rights to some of her parents' land if her husband had insufficient land or if she married a migrant.

For the Bara living near the Zombitse-Vohibasia forest complex (Atsimo-Adrefana Region), Moizo (2001) reported that rice fields and upland cropland were transmitted to descendants along patrilineal lines, with women having only rights of access and use. A woman could own cattle, but once she left the village upon marriage, her brothers took care of the cattle. ${ }^{15}$

Among the Antemoro in Analavory (Vatovavy Fitovinany Region), Rasoamalalavao et al. (2011) found that only male children could inherit land that had been acquired by their parents through inheritance. However, women could inherit ancestral land (known as fatrange) if they didn't get married and remained in place. If a woman was rejected by her husband and returned to her village, the brothers had to provide her with land. If she subsequently reconciled with her husband and returned to his village, then the brothers could take back the land. Importantly, however, the land given to women who remain in the village and do not get married was of a lower quality than that given to men, and women only have usufruct rights to it.

Among the Sihanaka near Lake Alaotra (Alaotra-Mangoro Region), Jarosz (1991) found that women could inherit land but if they moved away when they got married, they typically sharecropped it out to their male relatives who remained in their ancestral village (Jarosz 1991). When a marriage dissolved, two-thirds of the land the couple had acquired in common was given to the husband, with the wife getting the remaining one-third. Jarosz (1991) found that women with access to land tended to devote more of their labour to market gardens and dryland crops, while sharecropping out their irrigated rice fields to men.

Gezon (1997) reported that among the Antankarana in northern Madagascar (Diana Region), both men and women inherited land. Of the 59 women she interviewed, $18 \%$ owned land. Most of the women landowners were either unmarried or widowed. Although women could and did own cattle, they gave them over to their father or brothers for caretaking since the care of cattle is viewed as a male activity. Gezon highlighted culturally-constructed gendered divisions in labour as a factor that limited women's control over productive assets, like land, irrigation water and cattle. Women were heavily engaged in market gardening, an activity over which they did exercise control. Women's lack of control over productive resources was exacerbated by their limited engagement in key decisionmaking spheres. However, like Valkonen (2018), Gezon noted that women that had social ties to powerful families could exert substantial influence in village and family decision-making processes.

15 Note that the guiding principle was that cattle stayed with the village, irrespective of the owner's gender. If a Bara man chose to live elsewhere, his cattle also remained in the village and were taken care of by a male relative (Moizo 2001). 
She also found that while women typically did not speak up at fokonolona meetings, some women were adept at influencing decisions behind the scenes through comments made to male elders or children. Gezon (2002:691) concluded that "women proactively use local and regional dispute resolution systems to ensure their continued access to resources and their continued ability to shape and transform them."

\subsection{Local land-use categories and associated tenure rights}

Tenure rights vary depending upon the land-use category. Here we provide examples of the variety of tenure rights associated with gardens and residential plots, seasonally flooded rice fields, upland cropland, grazing land and forests.

\subsubsection{Gardens and residences}

Among the studies included in our review, few discussed tenure arrangements for gardens and residences. In those that did, the tenure rights described resembled private ownership rights held at the nuclear family level (McConnell 2002; Pollini 2007; Thielsen 2016). McConnell (2002) reported that in Vohibazaha, gardens (known there as tanimboly) were located in valley bottoms near residences and were farmed using intensive cultivation practices. In that area, a distinction is made between tanimboly and potro, ${ }^{16}$ with the latter being gardens that have had shelters constructed in them. Tenure rights to potro are stronger than those for tanimboly since the presence of a shelter implies that the user has permanent control over the land. Tree-planting and the construction shelters solidify claims to land. Trees planted in gardens are also an indication that the user has permanent and exclusive rights (Pollini 2007).

\subsubsection{Agricultural land}

Ownership rights to agricultural land are generally held by lineages or clans. However, in areas where land suitable for agricultural purposes - particularly rice cultivation - is scarce, they may be held (and managed) by nuclear families or households (c.f., Pollini 2007; Di Roberto 2020). Possession of stateissued land titles is rare, and several studies reported that titles were unnecessary for land claims to be recognized locally as legitimate (Spack 2005; Cullman 2015 Valkonen 2018; Di Roberto 2020). Since 2005 , land certificates are more commonly issued than titles, but they too are relatively rare. Using data from a survey conducted in four regions in 2015, Di Roberto (2020) calculated the percentage of parcels with land certificates. The percentage ranged from a low of 4\% in Analamanga Region (Central Highlands) to a high of $19 \%$ in Diana Region (northern Madagascar). In many areas, like the Mivili area in northwestern Madagascar (near Marovoay in Boeny Region), there was no local land office at which to request a land certificate (Medernach and Burnod 2013).

Throughout Madagascar, the most fertile land is typically found in seasonally flooded lowland areas, often referred to as baiboho, which are devoted to rice production in the wet season and crops like tomatoes or onions in the dry season (McLain et al. 2019). In areas where seasonally flooded lowlands are scarce, such land tends to have the most privatized rights at the family level (c.f., Di Roberto 2020; Klein et al. 2007; Pollini 2007). In the areas peripheral to the Ambohitantely Reserve, which is located on the eastern edge of the Central Highlands, the valley floors that support rice fields cover a relatively small area and are subject to customary rights inherited within established families (tarikas) that farm them collectively (Klein et al. 2007). New immigrants to this area are typically tenant farmers, dependent on the established families for access to land. In areas historically dominated by

16 Messerli (2003) reports that in Beforona, which is also located near Mantadia National Park, the term potro refers to the shelter, rather than to the garden in which the shelter is found. Such shelters may be found on land used for swidden crops (tavy) as well as in gardens (tanimboly). The potro location changes from one tavy season to another, as the fallows can't be utilized in permanence. 
pastoralists, like the Mahafaly Plateau and adjacent coastal areas, Menabe Region and Boeny Region, the tompon-tany of the pastoralist societies occupying those areas initially gave in-migrants, notably Betsileo, rights to use baiboho in their territories for rice cultivation (Fauroux 2001; Medernach and Burnod 2013; Moizo 2001).

Hillside land suitable for growing dryland crops is known as tanety. ${ }^{17}$ In areas where land is still plentiful, rights to tanety are usually secured by clearing the land and planting crops on it (Klein et al. 2007). In many areas, tanety is less valuable than seasonally flooded lowlands. However, farming tanety can be lucrative depending on market demand for the crops grown, proximity to markets and transportation infrastructure. Households often cultivate their tanety fields separately rather than collectively.

In the Vohibazaha community near the Mantadia National Park, upland rice fields are grouped loosely by lineage surrounding highland family tombs (McConnell 2002). Extensive borrowing and lending of lands occurs within the community, along with reciprocal labour exchange. Here, upland rice fields are fallowed to renew their fertility, and use rights to those fields rest in perpetuity with the farmer who originally cleared them. Stands of trees located on fallowed lands are considered fady (taboo) and their use is forbidden (McConnell 2002). Ranjatson, co-author of this report, found that harvesting green trees from fallows was forbidden in Beforona, which is located near Mantadia National Park. However, standing dry dead trees (tsangamaina) were open access. Families owning the fallow land could cut live trees but only if they ran out of fuelwood, a practice known as mandazo, meaning 'make green trees fade'. The cut trees themselves are called lazo (faded tree).

In villages with land shortages, most land along river bottoms has already been distributed among the families (Gingembre 2017). In these areas, uplands (tanety) are being converted into fields to accommodate the land needs of the younger generation, thereby decreasing the land available for pasture and increasing the likelihood of herder-farmer conflicts.

\subsubsection{Grazing lands}

Most of the studies with details on rights to pasture lands focused on the Mahafaly Plateau (Moizo 2001; Goetter and Neudert 2016; Thielsen 2016), Atsimo Andrefana Region (Horning 2004) and Menabe Region (Fauroux 2001, Scales 2011). In these areas, grazing land is typically managed as commons, but with exclusive areas for the herds of some families or lineages. Grazing lands tend to be in uplands, where dryland crops may also be grown. Cattle herders use different zones within grazing commons for different purposes, and these zones have different tenure types. Horning's (2004:84) description of the Bara in Atsimo Andrefana Region illustrates how land use, social organization and tenure are intertwined:

"If one looks at Bara village territories, it becomes obvious that pastoralism dictates the terms of spatial organization. This is to say that spatial units are organized around cattle's needs. Within each village (tanana or tana), there are designated areas for parking zebus overnight (vaia).

Outside the (imaginary) circle of human settlements, and past agricultural fields (tanimboly), vast areas of savannahs (monto), forests (ala), rivers (where zebus drink and get washed) and gallery forests (sakasaka) and hilltops together constitute the pasture space, or pasture unit.

The savannah zone immediately outside the village (about one mile out) is usually designated as collective pasture. Beyond this collective pasture zone, each lineage has a designated area where it takes its members' cattle. Some of these are found inside forests. The toets 'aomby, which are temporary camps where members of a lineage watch the family cattle, are located between village settlements and forests. Although this is not explicitly said, these camps serve as monitoring posts to keep track of traffic on the village territory and into the forest.

17 In some parts of northwestern Madagascar, dryland fields are known as tanimboly (McLain et al. 2019). 
The physical organization of pasture areas is intricately linked to social organization, whereby each lineage contains its herds and controls the space on which respective herds graze. The village territory can thus be represented as a collection of lineal, clan, or ethnic zones in which each lineal space is organized in a predictable manner: there are specific areas where zebus are parked (vaia), where they are gathered (kija), where they eat, drink, get washed and rest. Finally, there are specific paths where they circulate, are inspected and counted (kizo)."

Among the Bara on the Ihorombe Plateau, founding villages hold collective rights (management, exclusion and allocation) to the communal rangeland (tany-pokonolona) and set the rules of use for members of other villages (typically access and use rights) (Gingembre 2017). Use of such territory often comes with obligations of assistance and reciprocity. Additionally, collective surveillance against cattle theft is practiced in this area. Every village whose land has been crossed by thieves has a duty to track the cattle; a village which cannot identify the exact place where the stolen cattle left its village land must pay compensation to the person whose cattle were stolen.

When grazing lands held as commons are converted to cropland, conflicts sometimes arise between herders and farmers. Such was the case in Bevary, near the Ankarana Reserve in northern Madagascar, where the fokonolona gave a farmer permission to dig a canal and clear a field in a portion of the communally managed grazing lands (Gezon 1999). Although grazing land in Bevary is not privately owned, locals recognized that particular herds had rights to graze in specific portions of the commons. The cattle who used to graze in that area continued to do so, causing damage to the farmer's crop. Ultimately the case was brought before the fokonolona, which decided that the farmer needed to fence his land to prevent future encroachments.

In some areas of southwestern Madagascar, locals began claiming more privatized types of rights 20 to 30 years ago in response to fodder tree (samata) scarcity (Goetter and Neudert 2016; Thielsen 2016). Box 3 describes the range of rights that now exist for samata. Despite numerous local and state attempts at restriction, such privatization enclosures are widely accepted by locals, who understand the motivation behind them given the scarcity of samata trees and their cultural practice of allowing community members to claim open land (Goetter and Neudert 2016). Nonetheless, community members fear that conflicts may arise with the "strongmen" who have been most active in marking off private enclosures.

\subsubsection{Forest tenure}

In areas of Madagascar where customary tenure systems are dominant, forests have multiple values and meanings. Forests provide subsistence resources (e.g., fuelwood, construction materials, food, game), function as a land reserve for future generations, and are sites where spirits and the ancestors dwell (Scales 2012; Cullman 2015). Forests, whether gallery forests, secondary forests, or wooded savannas are also arguably the landscapes in which customary tenure systems are most likely to be heavily impacted by the state tenure system. The 2005 land law specifies that lands occupied or placed into production are presumed to be privately owned, and therefore customary rights to most agricultural and residential land are recognized. However, even though many rural communities have long-standing customary claims to nearby forests or pasturelands, such lands are not considered occupied nor as having been placed into production (Aubert et al. 2013). As a result, most forested land (and pastureland) is either assumed to be in the state's public domain or, if the proper procedures have been followed, has a specific legal status, like a national park, natural reserve, or other type of protected area. However, because the state's capacity to manage forest land is limited, for all practical purposes, customary tenure rules continue to play an important role in shaping access and use of forests in much of rural Madagascar.

Since the enactment of the GELOSE law in 1995 and promulgation of the subsequent 2001 decree simplifying the co-management process, forest management contracts (CGF) have become the primary way in which communities can legally exercise rights to forests and rangelands that fall within their 


\section{Box 3. Privatization of a resource commons}

On the Mahafaly Plateau in southwestern Madagascar, Goetter and Neudert (2016) found that among the Tanalana ${ }^{1}$ inhabitants, private rights to Euphorbia stenoclada existed alongside open access rights to community grazing areas. Euphorbia stenoclada is a succulent tree used for cattle fodder and is referred to locally as samata. Access to samata has historically been open to all, except for samata located near private corrals. However, reduced rainfall, widespread conversion of samata pastureland to cropland and destructive samata harvesting techniques, have reduced samata populations, catalysing a shift toward privatization of this critical resource.

Goetter and Neudert (2016) documented three types of rights to samata:

1. Marked samata: These are trees located in community grazing areas, but which have been marked and claimed as private property using lines of cacti; includes rights to the trees but not to the land;

2. Corral samata: These are trees surrounding private corrals located on grazing commons; rights include the right to use the trees for fodder and to sell samata trees to others, but does not include rights to the land;

3. Samata enclosures: These are trees that are enclosed using fencing and which are sometimes open for use by all clan members; includes rights to the land as well as rights to the trees.

Conflicts about acceptable distance of private use around the livestock pen and the size of enclosures have been discussed at different levels (fokontany, commune, clan) for three decades but thus far no solutions have been found (Thielsen 2016).

1 The Tanalana are a subgroup of the Mahafaly.

territory (Aubert et al. 2013). Under the 2015 Protected Area Systems Law (Loi 2015-005 portant refonte du Code de Gestion des Aires Protégées), communities can use co-management contracts to acquire state-recognized management rights to protected areas. This law also specifies (Article 42) that management rules should seek to ensure that traditional norms and practices (dina, fady, sacred sites) observed by the local communities are respected.

The ways in which rights to forest lands and forest resources are allocated under customary systems vary across Madagascar, as does the capacity of communities to enforce their rules. In Makira National Park in northern Madagascar, where inhabitants are Betsimisaraka and Tsimihety, Cullman (2015) found that most forested land was allocated under the customary system to specific households or large extended families, rather than treated as a community-wide commons or open-access resource. Consequently, when an international conservation NGO sought to implement a forest management contract (CGF) for the buffer zone around the park with local communities under the assumption that the forest was managed communally, tensions soon emerged because individuals felt that their rights were being disregarded. Additionally, to signal that the park itself was off-limits to use, the NGO declared the park a taboo forest (alafady). This, too, angered local inhabitants who felt that the NGO had usurped authorities that properly belonged to their traditional leaders (tangalamena).

Elmqvist et al. (2007) examined access rules and enforcement for forest resources in four areas of Androy Region in southeastern Madagascar. In all four sites, state control was effectively non-existent with the result that either customary rules prevailed, or in some cases, neither state nor customary forest tenure systems were functional. In western Androy, which had a long history of extensive outmigration to other parts of Madagascar, the customary tenure system had broken down, leaving the forest effectively an open access resource: 
"According to local leaders, a customary practice is used to claim land, using cacti (Opuntia spp) to mark new borders, but the institutional mechanisms that regulate the practice are not in use, as the elders among the new inhabitants have no established authority over the land. In practice, there is an open access situation, with insufficient enforcement of formal rules and a malfunctioning customary system." (Elmqvist et al. 2007:7)

By contrast, the customary tenure systems continued to function well in northern and central Androy. Elmqvist et al. (2007) reported that new permanent settlers to the area must go through the clan authorities to acquire access to land, and that anyone who wishes to cut down a tree must get approval from the fokonolona, as well as from the state (fanjakana). However, enforcement against outsiders remained challenging in these two sites due to the low population density and consequent difficulties in monitoring forest use. In southern Androy, which has a higher population density, the customary system also continues to function. All forest patches have been allocated to clans or lineages, and some of the patches are designated as taboo forests, with restrictions on who can enter them and what resources can be harvested. Importantly, Elmqvist et al. (2007) found a positive relationship between the strength of the customary system and forest cover. The greatest reduction in forest cover occurred in western Androy, where the customary system had broken down and an open access system had emerged. In the sites where the customary systems continued to function well, forest cover remained stable.

Horning's 2004 study of rules-in-use for four forests in Ibara provides an instructive look at differences in adherence to rules depending on whether the forest rules are primarily communityderived or imposed by the state. Residents in villages located close to these forests harvest forest resources either for their own use (e.g., construction and fuel wood, food, medicine) or, to a lesser extent, for commercial sale (e.g., charcoal, timber, minerals). ${ }^{18}$ Community rules were least restrictive for food resources and most restrictive for commercial harvesting of either dead or live wood. Horning (2004) identified two distinct types of forest tenure situations among the forest communities studied.

1. Communities where local forest protection rules are strong. Forest protection was strong in the most remote communities near the Analavelona Reserve. Community members considered the forest to be the sacred home of the ancestors of their founding clans; they also valued it as a place where they could hide their cattle to avoid taxation. In the most remote communities, forestry rules were set by the lineage or clan leaders and generally abided by. The risk of being caught breaking the rules was high because local herders located in herding camps at the forest edges could easily monitor the area. Many locals believed they would receive supernatural punishment (illness or death) if they broke the rules. Community members were less likely to follow state rules, which they felt were too restrictive and didn't reflect local values, and which the state lacked the capacity to enforce. The effectiveness of the local rules was reflected ecologically: an analysis of satellite imagery between 1989 and 2004 found no detectable change in forest cover.

2. Communities where local forest protection rules are weak. In communities located further from the forest, and where many migrants or multiple ethnic groups were present, forest use rules tended to be based more on state rules than community rules. These communities were socially less cohesive, and traditional authorities were weaker than in communities where forest protection was strong. Forests near these communities suffered from significant deforestation and illegal forest uses, like the use of tavy to clear fields and commercial harvesting of lumber, fuelwood and charcoal. Commercial harvesting was facilitated by easy access to local markets. State management in these areas emphasized forest protection at the expense of local livelihoods, which Horning concluded may explain the widespread incidence of illegal forest exploitation.

18 Logging on a large scale is more likely to occur in areas where outside investors are engaged in resource extraction (Horning 2004; Pollini 2007). 
Sacred forests and trees are another important feature of customary tenure systems in Madagascar. Access and use of such forests are subject to different rules than those applied to other forested areas. Box 4 describes examples of sacred forests among the Sakalava, the Tanalana and the Betsimisaraka. Based on work in Androy Region, Tengö et al. (2007:689) argued that "beliefs in the ancestors and their influence over daily life" are an integral component of local forest governance systems. They suggest that conservation strategies should emphasize understanding and building upon these beliefs, rather than using approaches that undermine them, like imposing state systems that are too rigid and based on values foreign to local community members.

Andriamalala and Gardner's (2010) case study of the dina for Velondriake, a large marine protected area in southwestern Madagascar involving multiple fokontany, provides an instructive overview of the process for creating co-management dina, as well as some of the challenges associated with enforcing these dina. For the Velondriake marine protected area, the community association (VOI), which was composed of members from the 24 fokontany located within or

near the marine protected area, began by holding a series of meetings to reach consensus on the rules to be included in the dina. This was done with the assistance of several well-funded external conservation NGOs. The president of the fokontany - designated as the sponsor for the community association - and the commune mayor signed off on the dina. Once the mayor signed off on it, the dina went into effect locally.

However, to be valid in the eyes of the state, and thus enforceable against outsiders, dina must conform with Madagascar's Constitution and its laws and regulations. As the first step in this process, known as homologation, the district head and relevant regional ministry authorities reviewed and approved the dina. In the final step of the process, the VOI took the dina to the president of the tribunal to verify that the document conformed with national laws. Having the tribunal's approval will ensure that the VOI is in a much stronger position should conflicts arise during enforcement. After the dina was approved, each village received a copy of the acceptance letter (letter d'homologation). In addition to specifying the rules governing resource use in the marine protected area, the Velondirake dina includes sanctions, known as vonodina, in the event that the rules are transgressed. The vonodina include fines as well as the seizure of illegally harvested products.

Among the challenges associated with implementing the Volondirake dina included: 1) reluctance to fine fellow community members; 2) lack of representation for some subgroups (i.e., women, youth and migrants) during the decision-making process, and their subsequent opposition and resistance to the rules; 3) conflict between cultural norms and national laws (i.e., sea turtle harvesting); 4) fines that were too high relative to the means available to community members; and 5) limited awareness of the dina and its contents among many community members.

Bérard's 2011 analysis of 32 dina developed for forest management contracts under the GELOSE law found similar problems. The new type of dina tended to follow a common template, drawn up by international conservation organizations, that neither took into account the ways in which communities traditionally regulate forest use, nor the realities on the ground. The emphasis of the new dina was on prohibitions along with associated fines for violations of the rules, an approach that Bérard points out is in direct opposition to traditional dina, which emphasize social cohesion over repression. Compliance with these dina 'vazaha' is often poor among community members. Since the GELOSE law specifies that the dina are applicable only to members of the communities that develop them, enforcement of infractions by outsiders is problematic for community authorities. Bérard attributes the gap between the new dina and what is actually needed on the ground to an outmoded view of the law, in which the state seeks uniformity and promotes a contractual approach, when what is needed is a better understanding of local conceptions of forest law, and strategies that will support those. 


\section{Box 4. Examples of sacred forest rules in Madagascar}

The Sakalava in the Central Menabe (western Madagascar) distinguish between the forest close to villages ( la ), the great forest (ala be), located at some distance from settled areas, and the taboo forest (ala fady) (Scales 2012). ${ }^{1}$ Collecting firewood and clearing the forest is prohibited in the taboo forest, and there are areas where even passing through is not permitted. Most taboos are related to links with the ancestors since family tombs are often located in taboo forests (Scales 2012). Large old trees, notably kily (Tamarindus indica) and renala (Adansonia grandidieri), are often sites for making offerings to the spirits. Fady regarding forest use apply to both zana-tany (persons born locally, literally people of the land) and vahiny (strangers).

Tanalana communities in and around Tsimanampesotse National Park in southwestern Madagascar have designated certain areas as sacred (Thielsen 2016). Local faly (taboos) prohibit the use of certain species of plants and animals and areas designated as sacred. For example, cutting trees is prohibited around tombs. The elders and supernatural beings are responsible for ensuring compliance with ancestral rules (lilin-draza), including faly. Place taboos apply to outsiders as well as community members. However, over time adherence to lilin-draza has declined, both among community members and outsiders. Thielsen (2016) attributes the decline in the legitimacy of traditional authorities in the area to a shift from traditional religious beliefs to Christianity among community members, increased in-migration of persons lacking kinship ties to local villagers, and the lack of alternative income possibilities.

Among the Betsimisaraka near Mantadia National Park in eastern Madagascar, the ancestral tombs of the first settlers are located on forested ridges (McConnell 2002). The area surrounding the tombs is known as sembontrano, and the conversion of forested sembontrano land to fields is tightly controlled by the clan patriarch (tangalamena) (McConnell 2002). A zebu sacrifice is required before sembontrano can be used for growing rainfed rice, and once the nutrients are depleted, the area must be left in fallow for at least 8 years. The area adjacent to the sembontrano is known as jingeranto. Although access to the jingeranto is less strictly controlled, these lands have scattered stands of trees that are considered taboo (fady), and which cannot be used (McConnell 2002).

Among the Antandroy living in Androy Region in southern Madagascar, Tengö et al. (2007) documented several categories of taboo forest patches, each with its own set of rules. These included 1) forest patches with tombs (ala kibory), where access was strictly regulated and a zebu sacrifice was required prior to any harvesting of resources; 2) forest patches without tombs (salata) where the dead were kept awaiting burial; although people and cattle could enter these areas, no resources could be harvested in them; 3) honey groves (ala fano-hofa) were dedicated to honey production; trees in these groves could not be cut but honey and dead wood could be harvested; 4) forest patches with spirits; these were old growth forest patches and were considered very dangerous; 5) private forests; owners could harvest live trees and harvest other resources or grant others permission to do so; 6) ceremonial forest patches; generally only healers and diviners had access to these areas; 7) memorial forest patches; these included areas that had once been royal settlements, mass graves and battlefields. Enforcement of the rules for taboo forests rested with the clan owing the forest patch.

1 In her ethnography of the Sakalava in Menabe Region, Goedefroit reported that inhabitants also made a distinction between ala be (large forest) and ala mandiniky (small degraded forest). 


\subsection{Key drivers of land-use and tenure system changes}

Our review identified several key drivers of change in land use and customary tenure systems in Madagascar.

1. State policies and laws that fail to acknowledge customary claims to so-called 'unoccupied' lands, like pastures and forests, that are key components of village territories and crucial for community members' livelihoods. These policies hinder local community efforts to govern their lands holistically, and their weak legal position makes it difficult for them to protect themselves from outside groups - whether conservation organizations, seasonal or permanent migrants, mining companies or large-scale agricultural interests - seeking land and resources within those spaces.

2. Pressure on the national government from the international conservation community and donor agencies to establish conservation enclosures has resulted in the setting aside of 7.1 million ha of Madagascar's territory in protected areas, two-thirds of it during the past two decades (Gardner et al. 2018). Most, if not all, of the land falling within the new protected areas falls within the boundaries of established customary territories (Aubert 2013). These enclosures have reduced land and forest resources available to local communities, often without a corresponding increase in alternative livelihood opportunities (Blanc-Pamard 2012).

3. National economic development policies that encourage large-scale land acquisitions for biofuel plantations (Medernach and Burnod 2013; Gingembre 2017), agribusiness (Rasoamalalavao 2011) and mining (Seagle 2012) have reduced land and resources available for rural communities. In recent years, outside investors have tended to lease lands that state or local officials consider 'unoccupied', but which local communities have long used as either cattle pastures or land reserves for agricultural expansion. In some areas, neighbouring villages are pitted against each other, with some seeing mining and agribusiness as a potential source of long-term employment, and others objecting to the loss of lands necessary for their livelihoods (Medernach and Burnod 2013; Gingembre 2017).

4. Successive waves of in-migration, together with associated economic shifts from pastoralism to sedentary agriculture, are a major driver of land-use and tenure changes on the Mahafaly Plateau and adjacent coastal area (Moizo 2001) and in Menabe Region (Fauroux 2001). In both areas, the influx of migrants seeking land to farm, has been accompanied by increased deforestation ${ }^{19}$ and disruption of transhumant ${ }^{20}$ pastoralists' ways of life. At the same time, structural changes in the local economies have provided an opening for wealthier in-migrants to gain greater political power, with a corresponding weakening of the power and perceived legitimacy of traditional authorities. Multiple factors have contributed to increased migration, including land scarcity in the Central Highlands (Poulain and Razanakoto 2014); prolonged drought in southern Madagascar linked to climate change (IOM 2019); government policies supporting agribusiness development, with an associated increase in the need for wage labour in areas where populations are still relatively low; and the emergence of strong export markets for certain crops, like maize (Scales 2011).

5. Internal population growth is also affecting tenure systems in many rural communities. Madagascar has a population growth rate of $2.7 \%$, with much of the increase occurring in rural areas (UN 2019). In many parts of the Central Highlands, as well as in parts of the Southern Highlands and on the Mahafaly Plateau, lands suitable for growing paddy rice are completely

19 Jones et al.'s (2018:13) study of migration to forest frontier areas in eastern Madagascar "found no evidence that migrants were more likely to have cleared land from forest or to have cleared a larger area of land than nonmigrants". They attribute increased deforestation in their study area to the increase in demand associated with in-migration rather than to the land-use practices of the migrants.

20 Transhumance is a type of pastoralism or nomadism, a seasonal movement of livestock between fixed summer and winter pastures. 
occupied, with associated pressure on upslope lands (tanety) to grow rainfed rice or other crops. The demand for tanety, in turn, has reduced the land available for grazing, disrupting pastoralist livelihoods.

6. Changing sociocultural norms are also affecting tenure systems in ways that are beneficial for some and detrimental to others. National laws that provide women with equal rights to land provide a foundation on which some women have been able to gain greater access to land in their own right. Participatory forest management processes, despite their flaws, have opened up spaces where previously marginalized community members may have an opportunity to have a voice in decisions that affect their access to land and resources. On the negative side, as norms change, traditional systems that have provided protection for forests are falling into disuse in some areas. When coupled with a weak and corrupt state, areas that once were managed as commons and subject to regulation, however limited, have shifted into de facto open access regimes.

7. Climate change that has brought about more extreme weather patterns (i.e., reduced and more erratic rainfall, more intensive flooding, and temperature extremes) is placing pressure on areas, like the Ihorombe Plateau, which were already vulnerable to flooding, drought and locusts (Gingembre 2017). In southwestern Madagascar, the reduction in annual precipitation has reduced the amount of fodder, placing greater pressure on areas where samata fodder is still available (Goetter and Neudert 2016). Faced with prolonged crop shortages and declining supplies of livestock fodder, many inhabitants of southern Madagascar have migrated, either temporarily or permanently, to areas that have a greater abundance of productive land (Poulain and Razanakoto 2014) ${ }^{21}$.

\subsection{Key research gaps}

A surprisingly large number of publications - whether chapters in ethnographic reports, technical reports for international organizations or the Malagasy government, books, or articles in scientific journals - touch on customary tenure systems in Madagascar. Although very useful, this wealth of material has some weaknesses in terms of the coverage that it provides on tenure systems, and in particular on those parts of the system that are managed as communal resources. Some of the areas where research appears to be quite limited are described below.

1. Geographic gaps: Our search found that customary tenure studies published since 1990, particularly those related to forests, tended to be concentrated in the following geographic areas: Mahafaly Plateau and associated coastal plains, Ranomafana-Andringitra-Ivohibe (RAI) Forest Corridor, Mantadia-Zahamena Forest Corridor, Ihorombe Plateau, Menabe Region, and the Central Highlands (especially around Lake Alaotra and in Vakinankaratra Region). We found comparatively few studies from regions in the northwest, north, northeast, south and southeast.

2. Ethnic group gaps: The customary tenure systems of the Antakarana, Bara, Betsileo, Betsimisaraka, Merina, Sakalava and Tanala were most heavily represented in the literature we reviewed. Although our review was not intended to be comprehensive, we undertook a very intensive search for English and French language materials post-1990 which still did not reveal many studies of other ethnic groups.

3. Gender gaps: We found only a handful of studies that provided more than a cursory description of women's land and forest rights, or their role in forest and land governance decisions. Most of the studies that provided reasonably in-depth discussions of women's rights and roles in

21 Canavesio's 2015 research on migration in southern Madagascar showed that climate change in itself is not the cause of out-migration, but rather it acts as a catalyst for migration in a context where the socioeconomic system is extremely fragile due to chronic social, political and economic crises. 
customary tenure systems were done in the 1990s or early 2000s. There is a pressing need for in-depth case studies of women's tenure rights and their roles in land and forest governance in all parts of Madagascar.

4. Grazing land tenure in central, northwestern, northern and eastern Madagascar: The literature on tenure for pasturelands is extremely heavily skewed toward the south and southwest regions of Madagascar. Very little research has been done on customary grazing tenure in the north, northwest, northeast, east and Central Highlands. Given that cattle are economically and symbolically important throughout Madagascar, this is an area where research on pastoralist tenure systems is much needed.

5. Fragmented reporting on tenure system components: Although many studies touch on some aspects of customary tenure systems in Madagascar, very few provide a comprehensive picture of who has what rights to which resources, when and under what circumstances. This is particularly true for forest and rangeland resources. Much of the discussions related to forest tenure focus either on clearing rights or rights to cut trees, with limited attention paid to rights relative to other products or other resources, like springs, marshlands or lakes.

In addition to these gaps, topical areas that we were unable to cover in depth, but which warrant further research, include:

- Agroforestry systems

- Reforestation and restoration programmes

- Decentralized land governance and land-use planning (i.e., to better understand the interface between commune-level and customary land governance systems)

- Forest and protected area co-management systems 


\section{Conclusion}

"While it is important for land reform to be strengthened, the objective is not to promote a mandatory and systematic formalization of individual or collective property rights. The objective is to insist on the actual recognition of local rights and on the decentralization of land management, as defined in the 2005 land laws, in order to protect the rights of local populations and, above all, to ensure the recognition of their power over land access." (Burnod et al. 2013)

1. Our review demonstrates that while customary tenure systems in Madagascar have a number of important characteristics in common, heterogeneity exists across and within ethnic groups as well as geographically. Consequently, a one-size fits all approach to recognizing customary tenure rights, including land allocation authorities, would likely prove counter-productive.

Indeed, a key lesson from the experiences with GELOSE and CGF is that using a standardized or formulaic template is a recipe for failure. Just as one would not even consider managing all forests in Madagascar - one of the most biologically diverse places on earth - using a one-size fits all template, so too must the diversity in tenure and livelihood systems be recognized and supported.

2. Our review also indicates the presence of dynamic heterogeneity in interests and relative power, both within and across communities. In some areas, wealthy cattle owners have an interest in conserving forests, which they use for grazing and as shelter for their herds, whereas community members who farm upland areas in those communities have an interest in clearing forests to increase their access to fertile land. Inhabitants of a hamlet close to a forest often have a different conception about what rules that should govern forest access and use than residents of more distant villages or seasonal migrants seeking to make a living from logging. Given the heterogeneity in interests present in even small communities, as well as the presence of often-longstanding power imbalances within communities, it would be a mistake to assume that elders or local authorities always speak on behalf of 'the community'. Indeed, it may be difficult to find individuals who can represent the views of even as small a geographic area as a fokontany. Elders and other local authorities may suppress the voices of other less powerful community members, like women, youth and migrants, or may make decisions that further their own interests at the expense of the broader community. This is likely why, in some land concession cases, economic elites who lacked political power negotiated side deals with investors (Medernach and Burnod 2013).

3. When linked with the legal texts review, this observation points to the need for careful consideration as to what the most appropriate institutions for governing communityheld lands are, in the event that land reforms to recognize customary tenure on commons are implemented. Much of the current discussion around customary tenure recognition focuses on the fokonolona as the most appropriate institution to exercise authority over state-recognized local commons. But fokonolona likely have never functioned as democratic bodies in most areas. Our literature review revealed that, in general, local leaders or a small group of persons are the ones who make decisions, rather than decisions being based on broad-based consensus derived through an inclusive deliberative process.

4. There is an assumption on the part of land reform proponents that once community rights to their land are recognized that the lands within their territories will continue to be held and managed at the community level. Yet, it may be the case that once their claims are recognized, members and leaders of some communities will decide of their own accord to grant private lands to their own members, a practice that our literature review suggests occurs somewhat frequently in present-day customary systems. Indeed, the hope of being able to convert the forest to cropland at some future point may be a motivating factor for some COBAs. 
5. We believe that it would be prudent to acknowledge that there are considerable differences in the capacity and political will of communities to manage their commons. Based on our review, we put forth the following hypotheses.

Hypothesis 1 - In areas where social cohesion is high, customary systems remain largely functional and seem to provide reasonably stable and effective frameworks through which rights to access, use, manage and transfer land or resources are allocated and enforced, and over which conflicting claims are adjudicated.

Hypothesis 2 - In areas where social cohesion has broken down, often through a restructuring of the local rural economy which undermines the traditional authorities' political authority, community members and outsiders are more likely to make use of the state system. Since both systems are weak, one would expect to see greater conflict in such areas.

Research that explores these hypotheses in more detail can help shed light on what constitute the key elements of functional customary tenure systems - as well as for whom, and in what sense, they are functional and for whom they are not. Such research can begin to help identify those elements of the system that need to be modified so that they are both more inclusive and more equitable in how benefits and costs are distributed.

6. A final important point to make is that local institutions and governance are profoundly affected by the ways in which state and customary institutions interact. For example, although GELOSE allows for the transfer of management rights to grazing lands, as well as forests, up to now little attention has been paid to that aspect of the law. As noted previously, given the social and economic importance of zebu in Malagasy lives, this is an aspect of customary tenure that deserves further attention.

As this review indicates, the positive effect of rules governing land and resource rights and use on conservation outcomes is contingent upon the degree to which those making and enforcing the rules are perceived to have legitimacy, as well as the degree to which the rules reflect local realities and values. This argues in favour of providing clear statutory recognition of local-level customary institutions, and their authority to establish and regulate use of land and forests. However, the performance of local customary institutions should be made accountable to public expectations that land and forest rights will be allocated fairly and managed sustainably. Hence, appropriate forms of oversight and regulation by state bodies are important and legitimate, provided the rules do not have the perverse effect of undermining the community's ability to manage resources effectively. 


\section{References}

Andriamalala G and Gardner C. 2010. L'utilisation du dina comme outil de gouvernance des ressources naturelles: Leçons tirés de Velondriake, sud-ouest de Madagascar. Tropical Conservation Science 3(4):447-472.

Aubert, S, Rambintsaotra, S and Razafiarijaona, J. 2013. L'insécurité foncière dans et autour des Aires Protégées de Madagascar : un obstacle à surmonter pour la conservation de la biodiversité et le développement rural. Développement Durable et Territoires 4(1):1-24.

Barry LS, Bonte P, D’Onofrio S, Govoroff N, Jamard J-L, Mathieu N-C, Porqueres i Gené E, Wilgaux J, Zempléni A and Zonabend F. 2000. Glossaire de la parenté. L'Homme 154-155:721-732.

Bérard M-H. 2011. Légitimité des normes environnementales dans la gestion locale de la forêt à Madagascar. Canadian Journal of Law and Society 26(1):89-111.

Berger L. 2006. Ways of the ancestors, ways of development: The Ankaraña peoples facing globalization. Etudes Rurales 2(178):129-160.

Bidou J-E, Droy I and Fauroux E. 2008. Communes et regions à Madagascar: De nouveau acteurs dans la gestion locale de l'environnment. Mondes en Développement 141:29-46.

Blanc-Pamard C. 2012. La gestion contractualisée des forêts en pays Betsileo et Tanala (Madagascar): Un dispositive dyssymétrique. Cahiers d'Outre-Mer 257:47-82.

Blanc-Pamard C and Fauroux E. 2004. L'illusion participative: Exemples oust-malgaches. Autrepart 31:3-19.

Boué $\mathrm{C}$ and Colin J-P. 2018. Land certification as a substitute or complement to local procedures? Securing rural land transactions in the Malagasy highlands. Land Use Policy 72:192-200. https:// doi.org/10.1016/j.landusepol.2017.12.049

Brown, ML. 2004. Reclaiming lost ancestors and acknowledging slave descent: Insights from Madagascar. Comparative Studies in Society and History 46(3):616-645.

Burnod P, Gingembre M and Ratsialonana RA. 2013. Competition over authority and access: International land deals in Madagascar. Development and Change 44(2):357-379. https://doi. org/10.1111/dech.12015

Canavesio R. 2015. Les migrations dans le sud de Madagascar: Entre sécheresses occasionnelles et crise socio-économique structurelle. Autrepart 2(74-75):259-278.

Covell M. 1987. Madagascar: Politics, Economics, and Society. London: Frances Pinter.

Cullman G. 2015. Community forest management as virtualism in northeastern Madagascar. Human Ecology 43:29-41.

Di Roberto, H. 2020. Le marché foncier, une affaire de famille? Une analyse institutionnelle des transactions de terres agricoles dans les Hautes Terres à Madagascar. $\mathrm{PhD}$ dissertation. France: University of Montpellier.

Elmqvist T, Pyykönen M, Tengö M, Rakotondrasoa F, Rabakonandrianina E, Radimilahy C. 2007. Patterns of loss and regeneration of tropical dry forest in Madagascar: The social institutional context. PLoS ONE 2(5): e402. doi:10.1371/journal.pone.0000402

Evers S. 2006. Expropriated from the hereafter: The fate of the landless in the Southern Highlands of Madagascar. Journal of Peasant Studies 33(3):413-444 https://doi. org/10.1080/03066150601062928

Evers S. 2001. Constructing history, culture and inequality: The Betsileo in the extreme Southern Highlands of Madagascar. PhD dissertation. Amsterdam: University of Amsterdam.

Fauroux E. 2002. Les sociétés rurales de l'Ouest malgache: Des transformations profondes et complexes. Afrique Contemporaine 202-203:111-132.

Fauroux E. 2001. Dynamiques migratoires, tensions fonciers et deforestation dans l'Ouest malgache. In Razanaka S, Grouzis M, Milleville P, Moizo B and Aubry C. eds. Sociétés Paysannes, Transitions Agraires et Dynamiques Écologiques dans le Sud-Ouest de Madagascar. Antananarivo: CNRE/IRD, pp. 91-105. 
Feller C and Sandron F. 2019. Parcours de recherche à Madagascar: l'IRD-Orstom et ses partenaires. Marseilles: IRD.

Fritz-Vietta NVM, Röttger C and Stoll-Kleeman S. Community-based management in two biosphere reserves in Madagascar - distinctions and similarities: What can be learned from different approaches? Madagascar Conservation and Development 4(2):86-97.

Gardner, C, Nicoll ME, Birknshaw, C, Harris, A, Lewis, RE, Rakotomalala, D, and Ratsifandrihamanana, AN. 2018. The rapid expansion of Madagascar's protected area system. Biological Conservation 220:29-36.

Gezon L. 2002. Marriage, kin, and compensation: A socio-political ecology of gender in Ankarana, Madagascar. Anthropological Quarterly 75(4):675-706.

Gezon L. 1999. From adversary to son: Political and ecological process in northern Madagascar. Journal of Anthropological Research 55(1):71-97.

Gezon L. 1997. Political ecology and conflict in Ankarana, Madagascar. Ethnology 36(2):85-100.

Gingembre M. 2017. Being heard: Local people in negotiations over large-scale land deals. A case study from Madagascar. PhD dissertation. Brighton, UK: University of Sussex.

Goedefroit S. 1988. La société Sakalava du Menabe: Approche anthropologique d'un ensemble regional de Madagascar. $\mathrm{PhD}$ dissertation. Paris: University of Paris I.

Goetter J and Neudert R. 2016. New rules are not rules: Privatization of pastoral commons and local attempts at curtailment in southwest Madagascar. International Journal of the Commons 10(2):617-64. https://doi.org/10.18352/ijc.743

Henkels D. 2002. A close-up of Malagasy environmental law. Vermont Journal of Environmental Law 3:1-16.

Horning N. 2004. The limits of rules: When rules promote forest conservation and when they do notInsights from Bara Country, Madagascar. PhD dissertation. New York: Cornell University.

International Organization for Migration (IOM). 2020. IOM Madagascar Annual report 2019. International Organization for Migration in Madagascar.

Jarosz L. 1991. Women as rice sharecroppers in Madagascar. Society and Natural Resources 4:53-63.

Jones PG, Mandimbiniaina R, Kelly R, Ranjatson P, Rakotojoelina B, Schreckenberg K and Poudyal M. 2018. Human migration to the forest frontier: Implications for land use change and conservation management. Geography and Environment. https://doi.org/10.1002/geo2.50

Karpe PM, Randrianarison M, Rambinintsaotra, S, and Aubert S. 2007. La pratique judiciaire dans le domaine foncier à Madagascar. Droit et Cultures 54:213-239.

Klein J, Réau B, Kalland I and Edwards M. 2007. Conservation, development, and a heterogeneous community: The case of Ambohitantely Special Reserve, Madagascar. Society and Natural Resources 20(5):451-467. https://doi.org/10.1080/08941920701211900

Kneitz P. 2016. Introduction: La paix du fihavanana. In Kneitz P. ed. Fihavanana - La Vision d'une Société Paisible à Madagascar: Perspectives Anthropologiques, Historiques Et Sociologiques. $2^{\text {nd }}$ edition. Halle an der Saale, Germany: Universitätsverlag Halle-Wittenberg, pp. 15-72.

Lambek, M and Walsh, A. 1997. The imagined community of the Antankarana: Identity, history, and ritual in northern Madagascar. Journal of Religion in Africa 27(3):308-333.

McConnell WJ. 2002. Misconstrued land use in Vohibazaha: Participatory planning in the periphery of Madagascar's Mantadia National Park. Land Use Policy 19:217-230.

McLain R, Ranjatson P, Lawry S, Rakotonirina JM, Randrianasolo R and Razafimbelo NT. 2019. Tenure challenges to implementing forest landscape restoration in northwestern Madagascar. CIFOR info brief no. 273. Bogor, Indonesia: CIFOR. https://www.cifor.org/library/7492

Medernach K and Burnod P. 2013. Recompositions inattendues d'un système agraire malgache par l'agrobusiness (Unexpected changes in a Madagascan agrarian system: The role of corporate agriculture). Études Rurales 191:63-76.

Messerli P. 2003. Alternatives à la culture sur brûlis sur la Falaise Est de Madagascar: Stratégies en vue d'une gestion plus durable des terres. African Studies Series A17. PhD dissertation. Bern, Germany: University of Bern.

Moizo B. 2001. Controle de l'espace et enjeux fonciers en pays Bara: Les relations authochtonesmigrants. In Razanaka S, Grouzis M, Milleville P, Moizo B and Aubry C, eds. Sociétés Paysannes, Transitions Agraires et Dynamiques Écologiques dans le Sud-ouest de Madagascar. Antananarivo: CNRE/IRD, pp. 75-89. 
Muttenzer F. 2006. Déforestation et droit coutumier à Madagascar: L'historicité d'une politique foncière. PhD dissertation. Geneva: University of Geneva.

Ottino P. 1998. Les champs de l'ancestralité à Madagascar: Parenté, alliance et patrimoine. Paris: Karthala and ORSTOM.

Pollini J. 2007. Slash-and-burn cultivation and deforestation in the Malagasy rain forests: Representations and realities. PhD dissertation. New York: Cornell University. p. 776.

Poulain M and Razanakoto T. 2014. Migration à Madagascar: Profil National 2013. Geneva: OIM (Organisation Internationale pour les Migrations).

Raison J-P. 1991. Dynamismes ruraux et contrastes fonciers dans Madagascar en crise. Tiers-Monde 32(128):901-915.

Ranjatson P. 2011. La sécurisation des usages forestiers par les réseaux sociaux et l'économie: Deux exemples aux lisières de la reserve spéciale de Manongarivo et du corridor forestier Ranomafana Andringitra. Antananarivo, Madagascar: University of Antananarivo.

Ranjatson P, McLain R, Mananga J, Randrianasolo R, Razafimbelo T and Lawry S. 2019. Tenure security and forest landscape restoration: Results from exploratory research in Boeny, Madagascar. Paper presented at the 2019 World Bank Conference on Land and Poverty, Washington DC, 25-29 March 2019.

Rasoamalalavao C, Ratovonjanahary R, Rasoamampionona C, Razafitody JF, Razafindrahasy A and Harimanga A. 2011. La décentralisation de la gestion foncière à Madagascar: Cas des communes rurales de Sahambavy et d'Analavory. IS Academy: Land Governance for Equitable and Sustainable Development. Netherlands: LANDAC.

Rosés M. 2016. Fihavanana local, fihavanana national: Les usages d'une coutume juridique locale à Madagascar. In Kneitz $\mathrm{P}$ ed. Fihavanana - La Vision d'une Société Paisible à Madagascar: Perspectives Anthropologiques, Historiques Et Sociologiques. $2^{\text {nd }}$ edition. Halle an der Saale, Germany: Universitätsverlag Halle-Wittenberg, pp. 237-262.

Sandron F. 2016. Le fihavanana au quotidien. In Kneitz P ed. Fihavanana - La Vision d'une Société Paisible à Madagascar: Perspectives Anthropologiques, Historiques Et Sociologiques. $2^{\text {nd }}$ edition. Halle an der Saale, Germany: Universitätsverlag Halle-Wittenberg, pp. 263-277.

Scales IR. 2012. Lost in translation: Conflicting views of deforestation, land use and identity in western Madagascar. The Geographical Journal 178(1):67-79.

Scales IR. 2011. Farming at the forest frontier: Land use and landscape change in western Madagascar, 1896-2005. Environment and History 17(4):499-524.

Scheidecker G. 2016. Cattle, conflicts, and gendarmes in southern Madagascar: A local perspective on fihavanana gasy. In Kneitz P. ed. Fihavanana - La Vision d'une Société Paisible à Madagascar: Perspectives Anthropologiques, Historiques Et Sociologiques. $2^{\text {nd }}$ edition. Halle an der Saale, Germany: Universitätsverlag Halle-Wittenberg, pp. 129-156.

Schlager E and Ostrom E. 1992. Property-rights regimes and natural resources: A conceptual analysis. Land Economics 68(3):249-262.

Seagle C. 2012. Inverting the impacts: Mining, conservation and sustainability claims near the Rio Tinto/QMM ilmenite mine in Southeast Madagascar. Journal of Peasant Studies 39(2):447-477. https://doi.org/10.1080/03066150.2012.671769

Serva M and Pasquini M. 2020. Dialects of Madagascar. PLoS ONE 15(10):e0240170. https://doi. org/10.1371/journal.pone. 0240170

Sharp LA. 1993. The possessed and the dispossessed: Spirits, identity and power in a Madagascar migrant town. Berkeley: University of California Press. http://ark.cdlib.org/ark:/13030/ft6t1nb4hz/

Southall A. 1971. Ideology and group composition in Madagascar. American Anthropologist 73(1):144-164.

Spack S. 2005. Gestion environnementale décentralisée de la réserve spéciale de Manongarivo (NordOuest de Madagascar). PhD dissertation. Neuchâtel, Switzerland: University of Neuchâtel.

Tengö, M, Johansson, K, Rakotondrasoa, F, Lundberg, J, Andriamaherilala, JA, Elmqvist, T. 2007. Taboos and forest governance: Informal protection of hot spot dry forest in southern Madagascar. Ambio 36(8):683-691.

Thibaud B and Colin A. 2010. Tensions foncières et recompositions territoriales dans la basse vallée de l’Onilahy (Sud-Ouest Malgache). Annales de Géographie 6(676):697-709. 
Thielsen K. 2016. Which form of agreement works for community-based management? A case study from southwestern Madagascar. Madagascar Conservation \& Development 11(2):66-76. https:// doi.org/104314/mcd.v11i2.5

UN (United Nations). 2019. World Population Prospects 2019, Volume II: Demographic Profiles (ST/ESA/SER.A/427). United Nations, Department of Economic and Social Affairs, Population Division.

Valkonen AH. 2018. Conceptions, practices and power plays around the notion of tenure security: Examining the land policy development and implementation process in Madagascar. $\mathrm{PhD}$ dissertation. University of East Anglia, School of International Development.

Walsh A. 2002. Responsibility, taboos and 'the freedom to do otherwise' in Ankarana, Northern Madagascar. Journal of the Royal Anthropological Institute 8(3):451-468.

Widman M and Hart R. 2019. Joint land titling and household bargaining in Madagascar. Feminist Economics 25(4):211-239 https://doi.org/10.1080/13545701.2019.1665195

World Bank. 2006. Madagascar: Land and Property Review. Washington DC: World Bank.

World Bank. 2004. Décentralisation à Madagascar. Washington DC: World Bank. http://documents. worldbank.org/curated/en/807221468773390434/Decentralisation-a-Madagascar 



\section{DOI: 10.17528/cifor/008342}

CIFOR Working Papers contain preliminary or advance research results on tropical forest issues that need to be published in a timely manner to inform and promote discussion. This content has been internally reviewed but has not undergone external peer review.

A lack of information about the living customary systems that manage commons in Madagascar hampers efforts to identify the levels at which collectivities charged with allocating land and enforcing land claims should receive legal recognition. To help address this knowledge gap and inform ongoing legal reforms aimed at recognizing collective tenure, we reviewed relevant legal texts and field studies of Malagasy tenure systems. Our review of legal texts revealed that the lack of a clear legal definition of the collectivities located closest to rural villagers is a major obstacle to efforts aimed at recognizing the land allocation and governance rights of existing local institutions. At the same time, our review of field research of customary tenure systems demonstrates that these systems continue to function more or less effectively in many parts of rural Madagascar. The evidence also suggests that the positive effect of customary tenure systems on conservation outcomes is contingent upon the degree to which those making and enforcing the rules are perceived to have legitimacy, as well as the degree to which the rules reflect local realities and values. This argues in favour of providing clear statutory recognition of local-level customary institutions, and their authority to establish and regulate use of land and forests.

\begin{tabular}{|c|c|c|}
\hline CGIAR & $\begin{array}{l}\text { RESEARCH } \\
\text { PROGRAM ON } \\
\text { Policies, } \\
\text { Institutions, } \\
\text { and Markets } \\
\quad \text { Led by IFPRI }\end{array}$ & $\begin{array}{l}\text { The CGIAR Research Program on Policies, Institutions, and Markets (PIM) leads action-oriented } \\
\text { research to equip decisionmakers with the evidence required to develop food and agricultural } \\
\text { policies that better serve the interests of poor producers and consumers, both men and women. } \\
\text { PIM combines the resources of CGIAR centers and numerous international, regional, and } \\
\text { national partners. The program is led by the International Food Policy Research Institute (IFPRI). } \\
\text { www.pim.cgiar.org }\end{array}$ \\
\hline
\end{tabular}

\begin{tabular}{|c|c|c|}
\hline CGIAR & $\begin{array}{l}\text { RESEARCH } \\
\text { PROGRAM ON } \\
\text { Forests, Trees and } \\
\text { Agroforestry }\end{array}$ & $\begin{array}{l}\text { The CGIAR Research Program on Forests, Trees and Agroforestry (FTA) is the world's largest } \\
\text { research for development program to enhance the role of forests, trees and agroforestry in } \\
\text { sustainable development and food security and to address climate change. CIFOR leads FTA } \\
\text { in partnership with ICRAF, the Alliance of Bioversity International and CIAT, CATIE, CIRAD, } \\
\text { INBAR and TBI. }\end{array}$ \\
\hline & & FTA's work is supported by the CGIAR Trust Fund: cgiar.org/funders/ \\
\hline
\end{tabular}

\section{cifor.org | forestsnews.cifor.org}

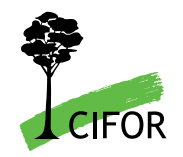

\section{Center for International Forestry Research (CIFOR)}

CIFOR advances human well-being, equity and environmental integrity by conducting innovative research, developing partners' capacity, and actively engaging in dialogue with all stakeholders to inform policies and practices that affect forests and people. CIFOR is a CGIAR Research Center, and leads the CGIAR Research Program on Forests, Trees and Agroforestry (FTA). Our headquarters are in Bogor, Indonesia, with offices in Nairobi, Kenya; Yaounde, Cameroon; Lima, Peru and Bonn, Germany.

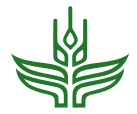

CGIAR 